Portland State University

PDXScholar

Spring 7-12-2018

\title{
Millennial Perceptions on Homeownership and Financial Planning Decisions
}

Margaret Ann Greenfield

Portland State University

Follow this and additional works at: https://pdxscholar.library.pdx.edu/open_access_etds

Part of the Economics Commons, and the Urban Studies and Planning Commons Let us know how access to this document benefits you.

\section{Recommended Citation}

Greenfield, Margaret Ann, "Millennial Perceptions on Homeownership and Financial Planning Decisions" (2018). Dissertations and Theses. Paper 4456.

https://doi.org/10.15760/etd.6340

This Thesis is brought to you for free and open access. It has been accepted for inclusion in Dissertations and Theses by an authorized administrator of PDXScholar. Please contact us if we can make this document more accessible: pdxscholar@pdx.edu. 
Millennial Perceptions on Homeownership and Financial Planning Decisions

by

Margaret Ann Greenfield

A thesis submitted in partial fulfillment of the requirements for the degree of

\author{
Master of Urban Studies \\ in \\ Urban Studies \\ Thesis Committee: \\ Lisa K. Bates, Chair \\ Greg Schrock \\ Andree Tremoulet
}

Portland State University

2018 
(C) 2018 Margaret Ann Greenfield 
This master's thesis investigates the economic factors that are affecting the financial decision--making of educated, middle to upper class Millennials in Los Angeles, California. This thesis explores how economic factors, preferences, and self-efficacy interact to determine housing pathways. This thesis also asks whether Millennials in Los Angeles will be able to afford homes and how the cultural narrative of the American Dream affects preferences. In order to answer these questions, twenty in person interviews are conducted with residents of Los Angeles in which they are asked about their values and preferences regarding housing, and the economic factors they are currently facing. This thesis finds that participants are struggling to navigate through economic factors such as student loans, a changing labor market, urbanization, highcost of living, stagnating wages, and high housing prices. This thesis finds that participants are experiencing low self-efficacy when it comes to finances, which seems to be a proportional reaction to the current economic climate. This thesis also finds that most participants want to own homes, however, in reality very few will be able to afford to buy homes in Los Angeles and will have to rent indefinitely. Lastly, this thesis finds that participants are rejecting the old American dream and that their preferences and values are different from baby boomers', however the housing market has not yet evolved to meet the demand of those changing preferences. 


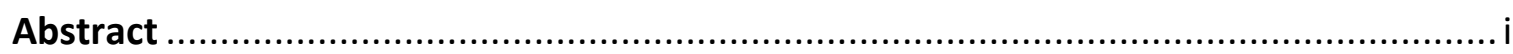

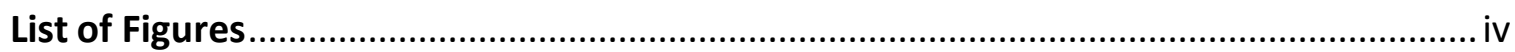

\section{Chapter 1}

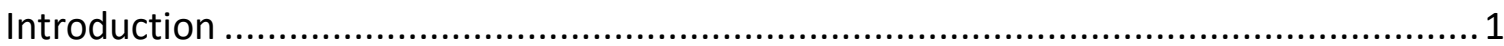

\section{Chapter 2}

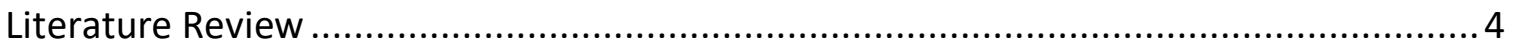

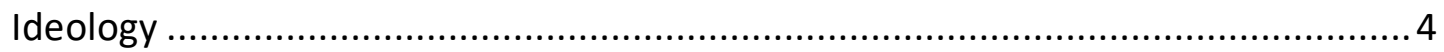

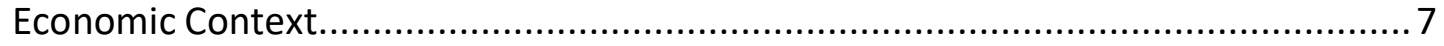

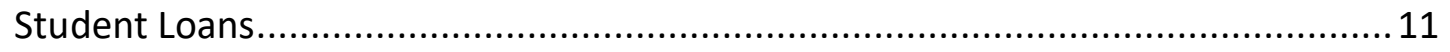

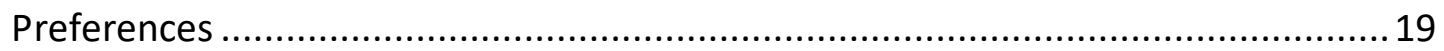

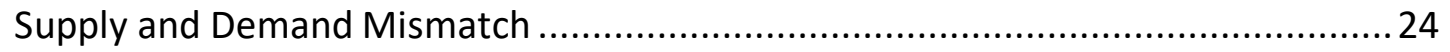

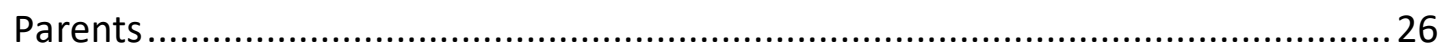

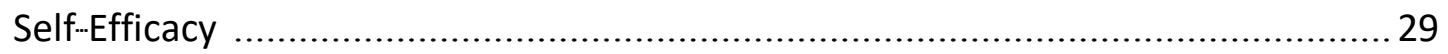

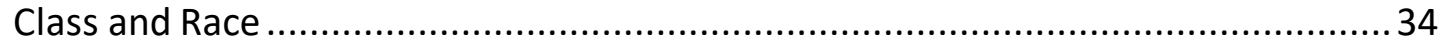

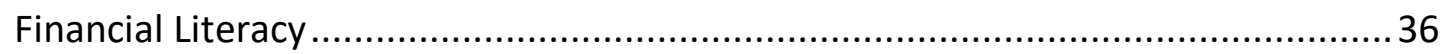

\section{Chapter 3}

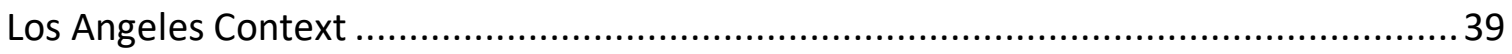

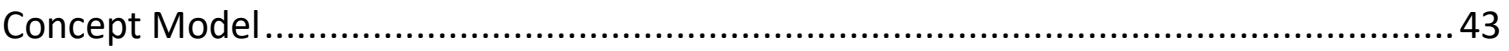

\section{Chapter 4}

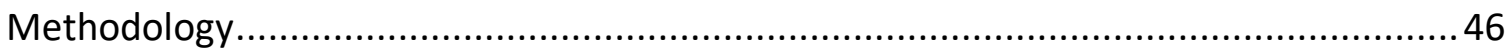

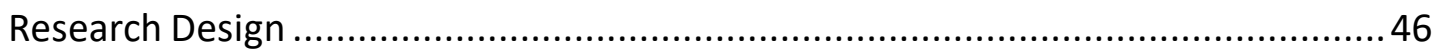

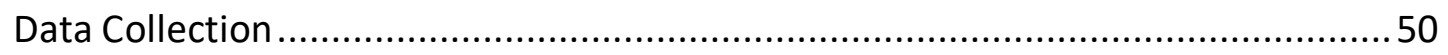

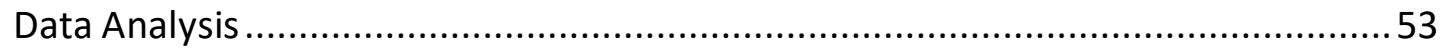

\section{Chapter 5}

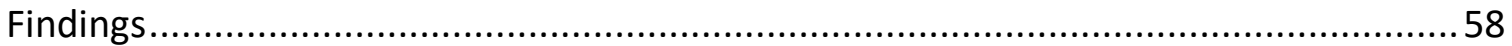

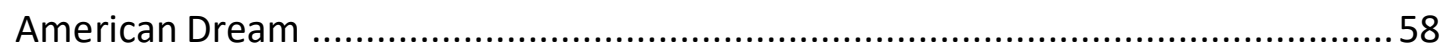

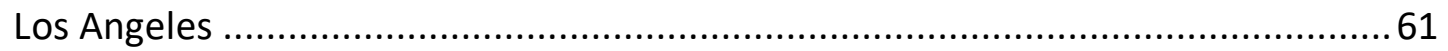

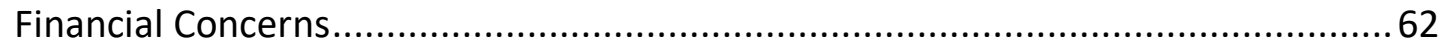

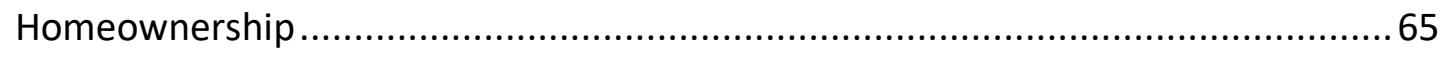

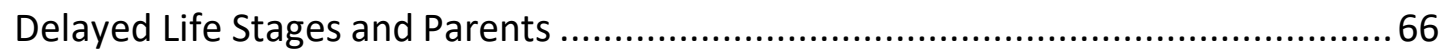

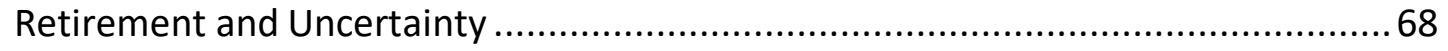

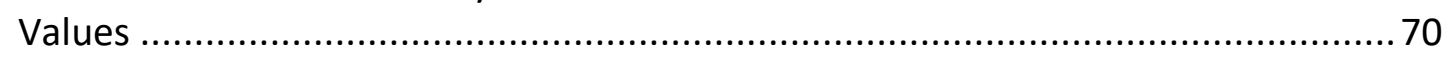

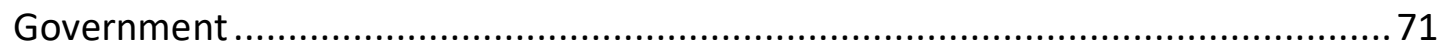

Alternative Housing Pathways/Models ......................................................... 72

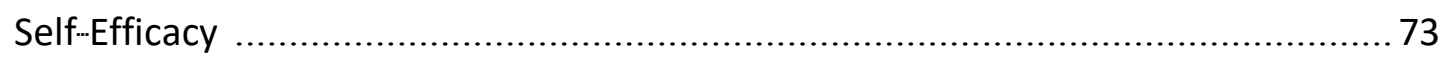


Thematic Map

\section{Chapter 6}

Discussion

Conclusion...

References.

Appendix A. Interview Questions 


\section{List of Figures}

Figure 1.1 Plans for Homeownership by ApartmentList....................................................2

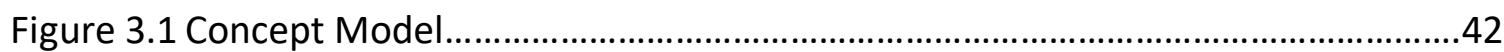

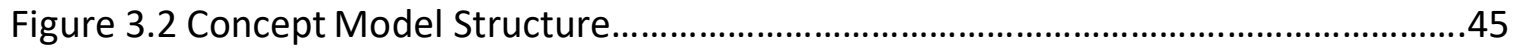

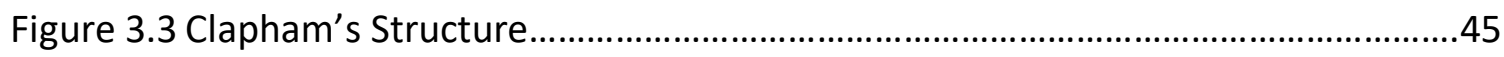

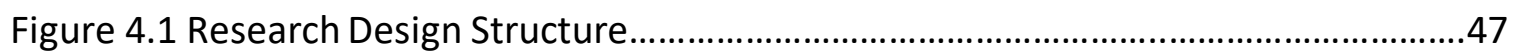

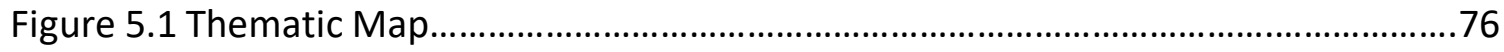




\section{Chapter 1: Introduction}

Owning a home is the one of the primary ways that Americans build equity and establish financial security. Currently, the Millennial generation is struggling with student loans, high housing costs, and a challenging labor market. Our current capitalist system in the United States is presenting obstacles in front of Millennials when it comes to accessing affordable housing and homeownership. This master's thesis discusses these obstacles and how Millennials are navigating them. This thesis also discusses the political and social ideas that are associated with the economic transaction of buying a home. This thesis explores how Millennials perceive homeownership in the United States, specifically regarding the accessibility and validity of the 'American Dream'. This thesis also explores how navigating the housing market and the current economy affect Millennials' self-efficacy and perceptions of their own agency within the economic system. This thesis then maps out how these factors-economic obstacles, attitudes, political narratives, and self-efficacy all shape the individuals' housing pathway. 

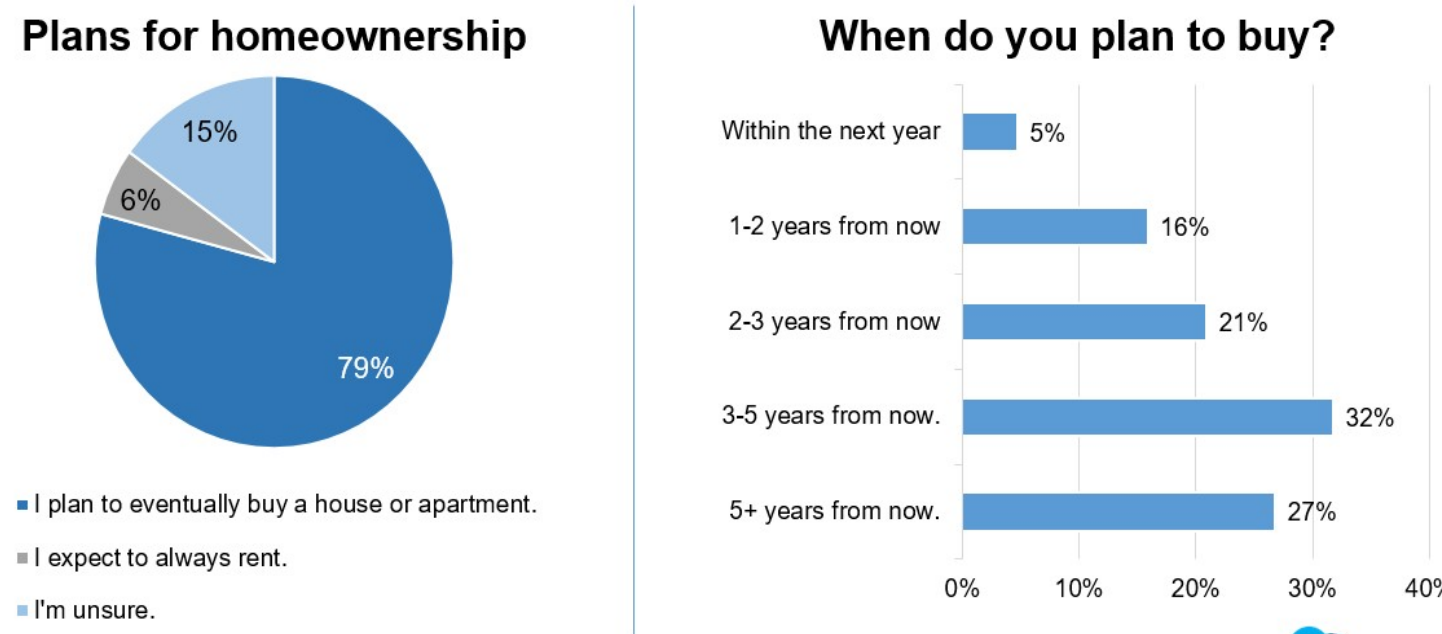

apartment $\mathcal{O}_{\text {list }}$

Figure 1.1 Plans for Homeownership by ApartmentList

As of 2015, there are 75 million Millennials (born between 1980 and early 2000s), thus they are the largest generation in the labor force (Bylund et al, 2015).

Seventy-five percent of Millennials have the long-term goal of owning a home (Bylund et al, 2015). Although many Millennials say they are waiting to buy homes because they are waiting to settle down, affordability is still the biggest obstacle. It appears that most Millennials want to own a home eventually, however current income to home price ratios suggest that it won't be a possibility for many people, at least not for another decade. This thesis asks whether Millennials want to buy homes, what types of homes they want to buy, and whether they will be able to afford to those homes. This thesis will help policy makers understand how to support Millennials in becoming financially secure adults.

The purpose of this study is to understand how homeowner ideology is evolving for 
young generations and to voice concerns regarding the structure of the United States residential real estate market and its role in our economic and social welfare.

Homeownership has replaced state provided social security provisions, making it an almost essential tool for families to establish financial security. Many scholars believe that our current housing system exacerbates income inequality and encourages a culture of individualism and consumerism. Millennials have indicated a shift in ideology and values that might affect their choices regarding homeownership. However, this shift could be problematic for individuals if there is no other option for wealth building and financial security in our country. The goal of this study is to critique our national homeowner ideology and point out issues such as affordability and access within our current housing system.

My research questions are: Which external factors influence Millennials attitudes towards homeowner ideology and their own sense of self-efficacy? How then do attitudes towards homeowner ideology and sense of self-efficacy influence Millennials' financial planning decisions? Meaning, how have economic factors shaped Millennials' attitudes towards homeownership and their feelings of personal empowerment to achieve their own financial goals? How do Millennials' attitudes towards homeownership affect their financial decisions? 


\section{Chapter 2: Literature Review}

\section{Ideology}

This literature review walks the reader through the key topics outlined in the introduction and provides a summary of the relevant research done on these topics to date. The topics center on the challenges that Millennials face regarding homeownership, and the external economic factors that are affecting their financial decision making. The topics included in this first section of the literature review are homeownership ideology, the current economic context, affordability, late stage capitalism, and Millennials as human capital.

Homeownership has had a significant presence in the United States since the latter half of the 20th century and into the 21st century. Since 1950 more than half of American households have owned their homes (Census.gov). Many scholars have observed that there is an ideology surrounding the process of buying and owning a home. By ideology, I mean the political and social ideas that are associated with the economic transaction of buying a home. Housing scholar Richard Ronald (2008) says that ideologies are "...everyday meanings and practices embedded in the flows of discourses which regulate flows of power in society" (p. 8). Put another way, ideologies are a complex set of power and social relations that structure the relationship between state, market and individual (Ronald, 2008, p. 8). Homeowner ideology, and in this thesis the American dream narrative, promote complex social relations that actively support homeownership and our current housing system. 
Most housing scholars agree that the United States is a 'homeowner society' because it advances policies that benefit homeowners. Dutch housing scholar Wouter P.C. van Gent (2010) writes, "In countries such as the UK and US the liberal welfare state has combined with a homeowner society" (p. 735). The equity gained from owning the asset of a home provides financial security that replaces pension plans, state--provided social security, etc. (van Gent, 2010, p. 736). This structure places the responsibility of long-term financial security and retirement upon the individual. This is a foundational aspect of homeownership ideology-it complements mainstream American ideologies of individualism and responsibility for oneself. UK housing scholar Susan Smith (2005) points out that housing as a retirement plan means that the individual absorbs the risk and responsibility of retirement (p. 35).

Wouter P.C. van Gent (2010) highlights two neoliberal narratives that he believes have constructed UK and US housing policies. The first is that markets and households should make capital gains from their assets; the second is that public spending is inefficient and accepting state welfare assistance is morally repugnant (p. 740). UK social scientist Prabhakar (2009) argues that the asset--effect, a concept proposed by Washington University in St. Louis professor M.W. Sherraden in 1991, has changed widespread ideology regarding how Americans should make their money. It has replaced basic income with basic capital. The policies that aim to provide individuals with basic capital are different from those that provide basic income (Prabhakar,2009, p. 54). Van Gent (2010) argues that homeownership discourses assign recommended norms regarding housing tenure to the following aspects of American social, political, 
and economic life: social status, autonomy and control, responsible citizenship and family life, economic advantages and security (p. 740-41). The practice of widespread homeownership in the United States has affected our culture, politics, and financial outcomes.

The home has multiple functions - it is a financial asset, an emotional comfort, a center for community, a retirement plan, a representation of belonging, citizenship, and patriotism. Homeownership has been marketed so effectively throughout history that owning a home represents the American dream and in some cases is synonymous with American citizenship. Eric Pido (2009) writes about Filipinos in Daly City, and how this population reacts to being historically excluded from citizenship by buying homes in suburban neighborhoods. Pido argues that the Filipino concept of 'being American' is informed by a conception of the American dream that entails homeownership in suburban neighborhoods (p. 40). Pido says that immigration literature has generally explained the movements of immigrant communities with rational choice and economic impulse. He pushes back on these theories, arguing that many immigrant communities, such as the Filipino community in Daly City, choose to settle in specific places primarily in order to perform citizenship through homeownership (p. 38).

In conclusion, homeownership has shaped American history and it still shapes our present. Millennials' hesitancy to engage with homeownership means that they are potentially redefining cultural narratives of the American dream, growing up, property ownership, and financial success. The next section of this Literature Review discusses 
the external economic factors that are affecting Millennials' decisions regarding homeownership and financial planning.

\section{Economic Context}

The following statistics give a brief summary of the economic context that Millennials now face: since 1980 median family income has increased by 25 percent, median home price has increased by 60 percent, and the average cost of undergraduate tuition has increased by 160 percent (Salvioti, 2018, para. 1). These changes in our economic context are the ones most significantly affecting the nature of Millennials' participation in the housing market.

Many Millennials have observed or experienced their parents' loss of wealth during the Great Recession in 2008. Observing and experiencing the collapse of the United States real estate market and the subsequent global recession may have given Millennials a new perspective on owning a home. The recession showed that home values are subject to global market trends. Millennials may now see homeownership as a riskier investment.

Brazilian architect and urban planner Raqual Rolnik (2013) argues that homeownership has been taken over by finance, meaning that homes are no longer purchased and owned for decades, instead they experience numerous rapid transactions (p. 1058). Rolnik (2013) argues that the commodification of housing and its integration into global financial markets damaged access and availability of adequate affordable housing. He says that home prices and rents are indexed by global rather than local financial surpluses, which makes housing even less affordable (p. 1062). 
In 2002 the economist launched a global housing price index, which raised the total value of residential properties by 60 trillion in three years. Housing prices hit record highs compared to incomes and Rolnik (2013) argues that this price spike led to the housing bubble burst (p. 1062). The housing market has been integrated with other financial markets, thus normal homebuyers are competing with corporations and foreign buyers (p. 1064). In addition, Rolnik argues that the ability of capital to move rapidly from place to place in our global financial market, and the increasing privatization and financialization of the housing market has led to the transformation of housing from a social good to a wealth--building tool.

The founders of the website Zillow weigh in, "The good news is, the era of ignorant bliss is demonstrably, definitely over. Everybody understands that housing bubbles can pop. And we all want better, more accurate information to prevent bubbles from inflating in the first place" (Rascoff \& Humphries, 2015, p. 12). Millennials are aware that the housing market is more volatile than Americans had previously thought. However, real estate is still largely seen as a safe investment. Time will tell whether Millennials feel comfortable investing in real estate in the future.

Affordability is one of the primary factors influencing Millennials' financial decision-making. Although many Millennials say they are delaying homeownership because they are waiting to settle down, affordability might be a more significant factor than putting off marriage. According to a 2015 survey of 30,000 U.S. renters by ApartmentList, $79 \%$ of Millennials would like to buy homes in the future, but affordability is the biggest obstacle (Salviati \& Woo, 2017, para. 11). Less than 40 
percent say that they are delaying homeownership because they are waiting to get married or settle down. In San Francisco and New York, which are typically considered 'transient' cities, less than 50 percent of renters said they were delaying homeownership due to marriage. This indicates that affordability, rather than lifestyle choices, might be the biggest factor influencing Millennials' housing tenure choices (Salviati \& Woo, 2017, para. 13). Affordability is a particularly significant obstacle on the West Coast-more than 80 percent of Millennials in Seattle, Portland, San Francisco, Los Angeles, and San Diego cannot afford to buy according to the survey. Even in smaller cities like Detroit affordability is still the primary concern (Salviati \& Woo, 2017, para, 22).

Additionally, the ApartmentList survey finds that Millennials in expensive metro areas underestimate how much money they would need for a down payment, sometimes by 50 percent. ApartmentList used starter home prices and average saving rates to calculate that most Millennial renters will need a decade or more to save 20 percent of a down payment (Salviati \& Woo, 2017, par. 6). Rodney Johnson, editor of the Boom \& Bust publication for Dent Research writes a piece on Millennials and homeownership. He says that new buyers are putting down less equity and using more financing. Johnson (2017) finds that, "Last year, 17\% of first-.time homebuyers-of both existing and new homes-financed $100 \%$ of purchase price.... An additional $29 \%$ of first-time buyers put down less than $5 \%$ of the purchase price" (p. 4). Because homes are so expensive now, first--time buyers can't afford to put down a large down payment, increasing the likelihood of default. 
Rodney Johnson purchased a home in Dallas, Texas for $\$ 86,000$ in 1992 . If the home value had increased at the same rate as inflation it would now be worth $\$ 153,000$. However, that Dallas house is now estimated to be worth $\$ 855,000$ on Zillow. Johnson (2017) writes, "It's not young people, particularly Millennials, don't want to buy homes, they simply can't afford it.... In years past, buyers could simply find affordable homes in the next new ring of homes around a city population center. That's not the case now" (p. 1-2). A Harvard report on remodeling argues that affordability is indeed Millennials' biggest challenge when it comes to housing, "The evidence suggests, however, that homeownership decisions by younger households have much more to do with affordability than location and lifestyle preferences" $(2017$, p. 3). The Harvard report finds that homeownership rates for people under 35 are higher in metro areas where homes are more affordable.

Renting is also expensive. A Harvard study says that the new normal for the rental market is that half of renters are cost--burdened (paying more than 30 percent of income to rent). The study points out that more middle-.income renters are paying a disproportionate amount of income towards rent. From 2001 to 2016, those making 3045k per year paid 37 percent and then 50 percent of income towards rent, while those making 45--75k per year paid 12 and then 23 percent. Those making less than $15 \mathrm{k}$ paid a shocking 83 percent of income towards rent, "Given the fundamental need for shelter, rent is typically the first bill paid each month. High housing costs erode renters' purchasing power, leaving little money left over for other essentials such as food, childcare, and healthcare" (Joint Center of Housing Studies, 2017, p. 4). HUD's Worst 
Case Housing Needs 2017 Report showed that the number of very low income households (making less than 50 percent of area median income) receiving assistance grew by 600,00 from 2001 to 2015 , while the number of very low income households grew by 4.3 million (Joint Center of Housing Studies, 2017, p. 5). Poor quality and unstable housing puts an immense cost on individuals and families. Both public and private entities need to collaborate in order to increase the stock of affordable housing through innovation, reducing development costs, and other methods (Joint Center of Housing Studies, 2017, p. 6).

To conclude, there are multiple factors that have combined to make affordability a significant obstacle for Millennials who are aspiring to homeownership or simply trying to rent in popular metro areas. These factors include inflation, the overheating of the housing market, low supply, and urbanization. Additional factors are that home prices are at a 30--year high, the cost of new construction is rising, lack of labor, and tight credit. The practical issue of affordability in terms of both renting and owning is a significant factor that influences Millennials' self-efficacy, financial decision-making, and housing pathways.

\section{Student Loans}

Higher education is an important piece of the Millennial puzzle. The fact that many Millennials are struggling with student debt has become fairly well known through social media. Student debt affects Millennials' ability to save for a down payment. Some experts worry about a student debt bubble burst when Millennials start defaulting on 
their loans. As of August 2015, the student loan debt clock showed an accumulated debt total of approximately $\$ 1.29$ trillion (Student Loan Debt Clock, 2015). Sociologist Malcolm Harris (2017) explains,

Between the years of 1979 and 2014, the price of tuition and fees at four-year non--profit US colleges, adjusted for inflation, has jumped 197 percent at private schools and 280 percent at public ones, accelerating faster than housing prices or the cost of medical care or really anything you could compare it to except maybe oil (p. 42).

The total amount student loan debt has increased faster than credit card debt, mortgages, and auto loans in the past decade (Glowacki, 2012).

Cost of attendance has increased exponentially and yet students and parents are not deterred. The prevailing logic is that investing in one's own potential is always a good investment, and that a diploma will translate into a job with a good starting salary. Debt bridges the gap between getting a diploma and getting a job. Although this logic remains steadfast in the American psyche, Harris (2017) argues that it is no longer true,

But while college applicants' faith in the value of higher education has only increased--at least in terms of what their willing to pay and how much debt they're willing to take on---employers has declined. Wages for college--educated workers outside of the inflated finance industry have stagnated or diminished, with real wages for young graduates down 8.5 percent between 2000 and 2012 (p. 43).

Additionally, an ApartmentList national survey finds that between 2005 and 2015 the average student debt burden of graduating college seniors increased by 70 percent (Salvioti, 2018). The return on investment is lowering while the cost of the investment is increasing.

Student debt has long..term financial consequences. For example, student debt negatively affects credit scores. According to Credit Karma, people between the ages 25 
and 34 have the lowest average credit scores (628.46), with the 18 to 24 age cohort as a close second. Josh Harris, a finance professor at Clemson University, says that homebuyers must have a credit score. He also says, "If a Millennial isn't working while they're in college, it's possible they won't be able to afford a home or qualify for a home within the first five, ten or sometimes even fifteen years out of school" (Coyne, 2016). Mark Andrew's Housing Studies article (2010) finds that increased student debt levels, new repayment profiles, and lender--imposed borrowing restrictions delay young adult homeownership,

On the one hand, successful graduates are expected to have increased their human capital and benefit from higher permanent incomes, implying a quicker transition to homeownership. On the other hand, lender--imposed borrowing restrictions interacting with higher student debt levels could substantially delay first--time house purchases (p. 40).

Andrews' study finds that impact of student debt on transitions into first--time homeownership is mediated by employment patterns and earnings profile. The expectation is that income will rise as education levels rise-this has been true in the past, however the shifting labor market and onset of unprecedented levels of student debt means that education/income or education/wealth or education/homeownership may no longer have positive correlations (Andrews, 2010, p. 40).

Student debt is already affecting homeownership rates. Thirty.-two percent of Americans in their 20s owned a home in 2007, and it decreased to twenty-one percent in 2016. According to a report from the Federal Reserve Bank of NY, thirty--five percent of that decline is due to student loans. The report says that the rise in education costs 
means less wealth accumulation and spending power for Millennials. Some experts suggest that states lower tuitions in order to stimulate youth spending (Lobosco, 2017).

Student debt is a significant national issue; however, it has not been sufficiently addressed by policy makers. Harris (2017) asks,

What kinds of incentives motivate lenders to continue awarding loans for tens of thousands of dollars to teenagers facing both the worst youth unemployment rate in decades and an increasingly competitive global workforce? Why do universities need so much more money from students and their families? (p. 45-46).

The Obama administration nationalized eighty--five percent of student debt in 2010 (Harris, 2017, p. 46). Now that the federal government bought out most of the student loan industry the trillion--plus amount of debt makes up thirty--seven percent of the federal government's assets. Treasury rates-the interest rates the government uses to borrow money-have been very low, leading the government to make enormous profits from the student loan debt. For example, from the 2014 cohort of borrowers the Department of Education made \$25 billion in revenue. Unfortunately, this hasn't translated into higher education becoming any cheaper. The average student debt went from $\$ 23,200$ to $\$ 28,400$ from 2008 to 2013 (Harris, 2017, p. 47--48). Higher education is certainly more accessible than ever, not because it is cheaper but because it is more affordable, meaning that no money down is required and everything can be financed through loans. Higher education extracts money from the future in the present-it charges Millennials unperformed labor, and Millennials gamble that they will find and perform that labor. One could argue that the funding structure of higher education is financially burdening our youth. 
Harris (2017) paints a stark picture in which Millennials endure the anxieties of highly competitive primary schooling, they get into college and then graduate with tens of thousands of dollars in debt. Meanwhile their degrees are becoming less of an advantage and more of a prerequisite. Harris (2017) points out that universities now resemble an industrial complex and that college sports represent a multi--billion dollar market (p. 5). Harris (2017) argues that the swelling of higher education administrative jobs and the shift of culture from academic to corporate are largely responsible for the uptick in tuition costs. Administrators raise tuition for construction projects because they need new attractions to win over students who will become wealthy alumni. Tenure--track and full--time faculty positions have been replaced by multiple adjunct positions and faculty salaries have not increased. Students pay high tuition costs, while business has become the most popular major by far as students feel the pressure to become valuable human capital.

To conclude this section, the following are additional statistics: 70 percent of grads leave college with student debt. 44 million Americans hold 1.3 trillion in student debt. Americans in their 30s hold an average of $\$ 34,033$ in student debt. Americans in their 20s hold an average of $\$ 22,135$ in student debt. Many young people decided to pursue graduate education because the job market was so bad after the Great Recession. Sandy Baum, author of Student Debt: Who Borrows Most? What Lies Ahead?, says that graduate students hold a disproportionate amount of the debt. To add onto this financial stress for Americans in their 30s, the average price of raising a child in 2017 is $\$ 233,610$ (Hess, 2017). 
Many scholars have noticed and written about the fact that bad jobs are getting worse, good jobs are getting better, and the jobs in between are missing. Improvements in productive technology have led to a decrease in labor costs while Millennials invest more and more in themselves to be prepared for a skill--based information economy. Workers are getting better while jobs are getting worse. There are major worker andjob market mismatches for Millennials right now, which have led to widespread unemployment and underemployment (Harris, 2017, p. 66). Sociologist Arne L. Kalleberg (2011) calls this trend in the labor market 'polarization',

The growing gap between good and bad quality jobs is a long-term structural feature of the changing labor market. Polarized and precarious employment systems result from the economic restructuring and removal of institutional protections that have been occurring since the 1970s; they are not merely temporary features of the business cycle that will self--correct once economic conditions improve (p. 15).

From 2009 to 2014 corporate profits swelled by 50 percent, while in the same period employee compensation only increased by 9.5 percent (Harris, 2017, p. 100). It is a good time to be an employer and a bad time to be an employee. Harris (2017) points out that the post--recession gains in the economy have gone to corporations and those who own real estate, stocks, and bonds. Those who do not own anything have seen little post-recession gain. Harris (2017) writes,

Increases in the value of stocks, bonds, and homes have driven recovery from the 2008 crisis, even though the recovery has been unevenly enjoyed.... Post crisis America has been a great place to own things and a really bad place no to.... It's worth understanding what is really at the end of the road for Millennials who do everything right. The best the job market has to offer is a slice of the profits from driving down labor costs (p. 100-103). 
Harris (2017) points out that the pressure to achieve that we now put on children-and that Millennials experienced as children-comes from a justified anxiety. It seems that our current economy has been structured around work. Jobs allow Americans to live and provide for themselves, raise children, and buy a house. Medical care and retirement support come from jobs. Harris (2017) writes,

We've put the reproduction of society in the hands of owners motivated purely by profit. As a result, the consequences of career success and failure are growing heavier as time goes on.... The increasing wealth division between American owners and workers gives some much -needed context for the central role competition plays in young people's lives (p. 68-69, 100).

Technology is an additional factor in the labor market; it evolves at such a fast pace that jobs evolve quickly as well. The landscape of jobs will change dramatically when artificial intelligence is introduced on a large scale. Millennials must hustle to be relevant and marketable. The labor market's dizzying pace makes renting and flexibility seem more appealing. The nature of jobs has changed dramatically since our parents were our age and that significantly affects housing options and preferences.

Urbanization is a concept that describes the phenomenon of large populations moving to urban centers, and the effects of those population movements. This demographic trend is occurring in the United States and all over the world. One of the main effects of this trend is an increased demand for housing and an insufficient supply to meet that demand. Therefore, housing costs in urban centers have increased dramatically in recent years. Los Angeles has always had a high cost of living because of its enviable weather and entertainment industry. However, prices have become even more inflated as the population has grown. The effects of urbanization are particularly 
striking in smaller case studies such as at the recent explosion of cities like Austin, TX and Portland, OR. Regardless of the many reasons why people move where they do, the fact is that urban centers are exploding and struggling to accommodate new residents. This is a significant economic factor that affects the housing market as a whole and Millennials' ability to participate in homeownership.

Harris (2017) points out that we define generations by significant events and shifts like wars, revolutions, economic disasters, changes in the mode of production or social relations, etc. We usually define generations by these things in hindsight. Our current definitions of Millennials are founded on stereotypes that have to do with technology, laziness, and avocados. He urges readers to consider the historical events that have produced Millennials as they are today (p. 10). Harris argues that the only way to understand Millennials is to look at the social and economic conditions under which we grew up.

Harris points out that Millennials were born into a time where capitalism is speeding up faster and faster and creating a challenging environment. The economy has changed so much over the past several decades-forcing people, or 'human capital' to keep up,

No one chooses the historical circumstances of their birth. If Millennials are different in one way or another, it's not because we're more (or less) evolved than our parents or grandparents; it's because they've changed the world in ways that have produced people like us. And we didn't happen by accident: Over the past forty years we have witnessed an accelerated and historically unprecedented pace of change as capitalism emerged as the single dominant mode of organizing society. It's a system based on speed, and the speed is always increasing. Capitalism changes lives for the same reason people breathe: It has to in order to survive. Lately, this system has started to hyperventilate: It's desperate to find anything that hasn't yet been reengineered to maximize profit, 
and then it makes those changes as quickly as possible. The rate of change is visibly unsustainable. The profiteers call this process 'disruption,' while commentators on the left generally call it 'neoliberalism' or 'late capitalism.' Millennials know it better as 'the world,' or 'America,' or 'Everything.' And 'Everything sucks' (p. 4-.5).

Millennials have been trained to be human capital. Harris (2017) explains, "Human capital is the present value of a person's future earnings" (p. 22). Millennials think of themselves as human capital since from a young age we were told that good grades translate into money and better life chances. The prevalence of capitalism in every aspect of life affects Millennials' mindsets. It seems that some Millennials embrace the capitalist system while others reject it.

\section{Preferences}

Many scholars' primary concern regarding Millennial hesitancy towards homeownership is the deferment of advancing through life cycle stages. Bylund and his coauthors discuss the factors that are postponing homeownership for the Millennial age cohort; the authors point out that demand for homeownership in this generation remains strong but structural factors may prevent many Millennials from buying homes and moving forward through life cycle stages. (Bylund et al, 2015).

Millennials are buying homes much later than baby boomers did. The homeownership rate for the under 35 age group fell from 43 percent in 2005 to a historic low of 31 percent in 2015 (Joint Center for Housing Studies, 2017, p. 3). The transition from renter to homeowner is often determined by income and family composition. According to the U.S. Census Bureau, in 1950 the average age that women 
got married was 20 for women, 23 for men. Now it is 27.1 for women, 29.1 for men. Marriage results in a pooling of assets that usually makes homeownership more affordable, in addition, marriage is the expected step that occurs right before buying a home (Humphries \& Woo, 2017). Without marriage, buying a home makes less sense both financially and culturally.

Deferment of advancing to the next life cycle stage can lead to decline in homeownership and what some social critics have dubbed 'Generation Rent'. UK housing scholar Kim McKee argues that there is a 'fundamental fracturing of young people's traditional housing pathways' occurring, and that the transition fromchildhood to adulthood is being stretched out. McKee (2012) argues that housing choices are constrained by societal structures, economic and social processes (p. 855). The pathways open to this current generation of young people are very different from the pathways that were open to baby boomers (Clapham et al, 2014). Owning a home is typically equated with adulthood, growing up, and the American dream. Millennials might be redefining these cultural associations.

In her 2017 article McKee draws on Foucault, Bourdieu, and Bauman to emphasize the role of housing consumption in providing social status. She argues that narratives and government intervention in the UK valorize owning over renting. McKee (2017) points out that although most young people aspire to own homes, in reality they will not be able to due to the economic constraints they face ( $p 318)$. She calls this dynamic a 'fallacy of choice'. Later in this literature review I discuss the concept of self-.efficacy and how it is affected by economic constraints. In the interviews I conduct for 
this thesis I find that participants' low self-.efficacy is due to a largely accurate appraisal of the economic constraints they face. McKee (2017) emphasizes the relationship between young people's subjective housing preferences and the objective reality of their housing pathways,

Furthermore, whilst our young people themselves denigrated private renting as problematic and 'flawed consumption' they nonetheless also deconstructed cultural norms regarding homeownership, articulating that this narrative represented a 'fallacy of choice'. Crucially, this reflected the inherent tensions between their subjective preferences in an ideal sense and the objective reality of navigating the housing market (in terms of their economic resources and options. available opportunities in local housing markets). Ultimately, housing 'choices' are not formed in a vacuum, but shaped and framed by broader structural forces (p. 331).

McKee (2017) points out that young people are aware of the disconnect between their aspirations and what is possible in reality. Similarly, in my sample size for this thesis, participants criticized the American dream as unattainable in reality.

University of British Columbia sociology professor Nathanael Lauster (2010) talks about the relationship between housing transitions and family transitions, suggesting that cultural change operates within this evolving link. Lauster uses symbolic interaction and conflict theory to illustrate the cultural change. Lauster assumes that familial categories give people meaning and social value, and that the value of these categories is defined by those in power, "status they derive from symbolic distinction helps justify their entitlements.... Symbols become roles, like spouse, parent, and homeowner, which are all performed" (p. 544). Renter and homeowner are symbols that we perform that have social meaning, and according to Lauster, that meaning is determined by our context and those in power. 
Lauster's article (2010) argues that housing provides a stage for our roles, and that it informs which roles we play. He says, "Inequality serves as an engine for privilege. -led cultural change, which in turn directs the drama of daily life" (p. 545).

Townsend's 2002 ethnography found that the roles father, worker, husband, and homeowner all depended on one another (Lauster, 2010, p. 545). Housing and family transitions are inextricably linked in our culture-however, the nature of that link is changing. Millennials' evolving relationship with housing might affect how they see themselves and the roles that they play in society.

The founders of the real estate website Zillow wrote a book called ZillowTalk. They comment,

In Hollywood's eyes, young professionals-from Friends to Seinfeld-should rent, while happy families in the 'burbs ought to own. This notion has been seared into the public consciousness, sometimes, without us even realizing it.... We take our cues from the expectations of our family and friends, from popular culture, and from our gut - for many people, the idea of owning a home is not a choice. It's a progression. It's how you know "real life" has begun. (Rascoff and Humphries, 2015, p. 28).

Rascoff and Humphries (2015) point out the role of Hollywood in Americans' ideas of when they ought to rent or buy, "Sometimes renting gets a bad reputation in our society. It's associated-rightly or wrongly-with transience, youth, and folks who haven't started their "real lives" yet" (p. 29-30). Hollywood makes it clear that when we are young and unattached we should rent, when we get serious and committed we should buy. The authors push back on these assumptions and argue that the decision to rent or buy depends on the location in question and how long the person plans to stay in that area. 
The Harvard report titled America's Rental Housing 2017 points out that renting has become more common across age groups and income levels and is no longer reserved for young urban types. The report (2017) points out that since 2010 the number of renter households in the United States has increased by 1 million annually. However, three government surveys show this number sharply decreasing in 2016 and 2017 (p. 1). The authors point out that the heating up of the rental market was partly due to the sharp drop in homeownership rates after 2004. Now that the economy has recovered, and the job market has improved since the housing bubble burst, and it appears that Americans are once again interested in homeownership. However, per the report (2017) projections, renter households will continue to increase robustly by 500,000 annually through 2025 (p. 1).

The Harvard report (2017) points out another important trend-high-income households (defined as 100,000 per year or more) drove 30 percent of the growth in renter households over the past decade (p. 1). This suggests that either homeownership is extremely expensive, or many households simply prefer renting, or both. The average age of renters was 40 as of 2016. The report (2017) also points out that homeowners are still overwhelmingly white while minorities make up 47 percent of renters (p. 1).

For many market researchers the most important question right now is how will Millennials spend their money? University of Arizona professor Arthur C. Nelson believes that in the next ten years two thirds of Millennials will look to buy suburban homes, one third will look for homes in the suburbs closest to downtown, and the small percentage who want an urban lifestyle will move to smaller cities since they can't 
afford to live in places like Los Angeles (Kirk, 2017, para. 10). Most housing experts anticipate Millennials to buy homes and participate in the housing market, just later in life than their parents did. The key questions are then what types of homes will Millennials buy, and where? The answers are found in Millennials' preferences. Preferences are shaped by a large number of factors and therefore are hard to predict. However, housing market demand reveals preferences, and right now there is a huge unmet demand for affordable rentals and starter homes.

Mankiw and Weil (1989) modeled per capita housing demand as a function of age, arguing that age was the primary factor determining housing demand. They also found that home prices depended on demand as defined by their model. Peek and Wilcox (1991) counter--argued that interest rates and construction costs were more influential factors in determining housing demand. Green and Hendershott (1996) linked 1980 census data with per capita household expenditures. They found that education and income defined housing demand. In sum, future demand for housing can be difficult to determine. Regardless of the reason, the demand for affordable homes and rentals has increased dramatically in recent years.

\section{Supply and Demand Mismatch}

The issue of affordability is exacerbated by a thin supply of affordable homes. Unfortunately, the number of affordable homes being built every year has been gradually decreasing -in 2016 fewer than 100,000 homes priced below $\$ 200,000$ were built nationwide (Joint Center for Housing Studies 2017, p. 4). This is in part because 
land, labor, materials, and regulatory fees have all increased in cost. The National Association of Home Builders surveyed builders in 2011 and found that in the previous 5 years the cost of land had increased by 26 percent, the cost of labor increased by 29 percent, and the cost of fees increased by 28.9 percent. The cost of building a basic three story apartment building increased by 8 percent from 2016 to 2017. (Joint Center for Housing Studies 2017, p. 3). Therefore, builders will typically lose money if they build a home priced under $\$ 300,000$ (Johnson 2017).

Most of the boom in rental construction has been single family. However, in 2015 there was a slowdown of single-family conversions and a boom in multifamily construction. Completion of new multifamily units averaged 300,000 annually over the past few years, which is the highest level since the 1980s (Joint Center for Housing Studies 2017, p. 2). The median asking rent for new apartments increased by 27 percent between 2011 and 2016. This cost increase is largely because new units are higher-end multifamily units in urban areas. As previously mentioned, labor and materials are particularly expensive, which incentivizes builders and developers to focus on luxury construction in order to make a profit (Joint Center for Housing Studies 2017, p. 2). The government needs to subsidize builders so that they can make a profit while building affordable rather than luxury housing. The supply side of affordable homes has been constricted as well as the demand side. During the foreclosure crisis investors bought tens of thousands of starter homes and turned them into rentals (Joint Center for Housing Studies 2017, p. 4). 
Data from the American Housing Survey shows that there is more demand for affordable units than luxury units. Class A rentals vacancy rate increased 1.5 percent to 6 percent in the 3rd quarter of 2017, while Class C rentals vacancy rates increased slightly but remained low at 4.1 percent (Joint Center for Housing Studies 2017, p. 3). In addition to affordable homes, there will be increased demand for smaller homes with unique features - such as green materials or in-law suites (Kirk, 2017, para. 12). In 2035 those looking for homes will be 90 percent under 35 or over 70 -and both groups look for homes with less square footage. To cater to this approaching demand, some homebuilders are starting to build less expensive homes after years of focusing on the upper end of the market. U.S. homes got smaller last year for the first time since before the recession. The median size of a new single.-family home slipped 2 percent in 2016, which is only the 3rd time it has fallen in the last 20 years (Kusisto, 2017). Builders, developers, and policy-makers need to work together to address the changing demands in the housing market.

\section{Parents}

It is common for parents to help their kids with a deposit, down payment, guaranty, etc. For individuals whose parents don't own a home it will likely be more challenging to attain one. The intergenerational transfer of housing wealth is an important element of class reproduction-it contributes to wider class divides in developed societies (Wilkinson 2009). When an individual has to rely on family for support, as opposed to government programs or assistance, class reproduction is more 
likely to occur. Australian housing scholars Val Colic.-Peisker and Guy Johnson (2012) point out that Millennials with a history of homeownership in their families will have a better chance of navigating the housing market and attaining homeownership than Millennials without that history (p. 739).

Colic--Peisker and Johnson (2012) say that young adulthood is when the individual imagines, plans, and aspires (p. 730). Bourdieu writes, “Family background, embedded in a specific cultural 'habitus', is crucial in shaping young people's aspirations, and families can help their offspring in realizing their aspirations and 'dreams' by mobilizing their economic and social capital" (Bourdieu, 2005, 19). Parents tell us indirectly as we grow up, whether we should expect to own a home or not. An individual might feel that it is possible or impossible depending on the messages they received from their parents and from the world as a child. In addition, parents pass financial knowledge and life skills down to their children. Therefore, this indirect influence on financial goals is backed by social and actual capital.

McKee (2012) points out that the housing system this generation has inherited leaves them at a disadvantage to baby boomers-creating a divergence between 'housing rich' and 'housing poor' age cohorts; the concern is that this generation of young people will be less well--off than their parents (p. 860). In 2013 the Urban Institute did a study on average net worth by age in 1983 and 2010, finding that over that period of time older households grew their wealth significantly while younger households' wealth grew very little or decreased. Households over 74 had their wealth increase by 150 percent or more. Other older households saw similar surges. Households ages 29 to 
37 saw a 21 percent decrease, while those in their twenties had a 5 percent increase (Harris, 2017, p. 96-97). The Urban Institute report points out that as society gets wealthier typically children out-earn their parents; however now younger Americans' wealth is no longer outpacing their parents.

The National Bureau of Economic Research compares absolute income mobility between generations. Baby boomers were 90 percent likely to out-..earn their parents while Millennials are 50 percent likely to out-.earn theirs (Harris, 2017, p. 97). The report says that this change has been caused by the increasingly unequal distribution of GDP rather than a lack of growth overall (Harris, 2017, p. 98). Harris (2017) points out that now more people are living with less wealth, as evidenced by the fact that for the first time this century, the average consumer owns less than 2 bank cards (p. 98). Student debt has not followed the trend of frugality, in fact it has exploded. A 2014 Pew Research Center study by Richard Fry finds that young college debtors are especially lagging in wealth accumulation. Millennials are currently lagging behind their parents in terms of wealth accumulation. However, the 'great transfer' is expected to place large amounts of capital into the hand of Millennials. Millennials are expected to inherit 30 trillion dollars from their parents (Robaton 2016).

'The great transfer' is a phenomenon that has not happened yet. Housing scholars and journalists believe that when baby boomers pass their wealth down to their children Millennials' buying power will explode and they will finally be able to afford homes. This will likely result in class reproduction because the wealth from the 'great transfer' will remain within families. 


\section{Self--Efficacy}

One of the research questions in this master's thesis is: how do the previously outlined economic factors influence individual Millennials' perceptions of homeownership ideology and their sense of self-.efficacy? To clarify, how have the economic changes of the past few decades affected Millennials' perceptions of the American dream narrative? And how do they see themselves and their own agency within this broader context? The interviews conducted for this master's thesis provide some insights into these questions. The interview data will be reviewed in later sections of this paper. The following section overviews literature relevant to this research questions.

In their report "The Social Costs and Benefits of Homeownership: A Critical Assessment of the Research," Rohe, Van Zandt and McCarthy (2001) investigate claims that tie increased self-esteem with homeownership. The authors point out that interest in homeownership has been justified by assertions that it benefits both individuals and society as a whole. Rohe and his coauthors (2001) find that homeowners are more satisfied overall than renters but the causality or explanation within that association is ambiguous (p. 4). The authors (2001) examine the claim that all aspects of health are thought to improve with homeownership; there have been no studies that prove causality (p. 2). The authors (2001) point out that the arguments regarding the benefits of homeownership assume that the experience will be a positive one, not accounting for unexpected problems or depreciation in value (p. 3). Rohe, Stegman, and Basolo (1997) conducted a survey of 145 homeowners and renters - they found no statistically 
significant difference in self-esteem between new homeowners and renters of similar income.

Rohe and Stegman (1994) did a study on the relationship between homeownership and self-esteem using Rosenburg's 10 factor scale. Self-esteem (one's perception of their own worth) can be influenced by how one is viewed by others, how one perceives themselves in relation to others, and how their actions relate to desired outcomes (Rohe \& Stegman, 1994, p. 5). The third aspect of self-esteem is similar to the concept of self--efficacy. Stanford University psychologist Albert Bandura (1997) defines self-.efficacy as the belief that one's actions can affect change or produce results, or the belief in one's ability to succeed in a task. When individuals achieve their goals, they see it as an affirmation of their own competence. Conversely, when they fail to achieve their goals they may view themselves as less competent, capable, or able to control the outcomes of their actions (Rohe \& Stegman, 1994, p. 5). The government and national discourses present homeownership as a financial goal that everyone should strive for and achieve. However, many Millennials feel like that is an impossible goal. The inability to achieve this goal or other financial goals will affect self-efficacy and self-esteem.

Linblad and Quercia also question why homeownership is associated with nonfinancial benefits; they point out that causality between homeownership and social benefits has been inferred rather than investigated. They analyze the following processes as potential causal factors - residential stability, financial interests, and psychosocial benefits. The authors (2014) find that these factors have an association with increased health and civic engagement, although it is difficult to identify causality. 
Their path analysis finds that the effect of homeownership shows in the amount of time lived in a home and perceived sense of control (p. 286). Per Linblad and Quercia perceived sense of control is a causal factor between homeownership and social benefits - it mitigates the effects of homeownership on an individual. This suggests that perceived sense of control is a central component in the construction of an individual's housing experience.

Feeling in control is part of having a strong sense of self-efficacy. Rakoff (1977) conducted in -.depth interviews and found that participants went through a self-.judging process in which they saw their own ability to own a nice home or improve their home as evidence of their failure or success in life (p. 93). Some researchers have argued that low--income homeowners do not have as much control over their homes as they had been promised. Financial instability can lead to foreclosure, inability to move to a location with better jobs, inability to maintain a home, etc. These things can negatively affect low-income homeowners and make them feel less in control than low-income renters (Rakoff, 1997, p. 96). This study shows that the inability to control one's living situation affects a person's sense of self-esteem and self-efficacy.

Clapham, Mackie, Orford, Thomas, and Buckley (2014) explore the economic factors that are driving changes in housing circumstances for young people in the UK. The first factor is unemployment -2011 boasted the highest unemployment rate for young people since 1992 in the UK (p. 2021). The second factor is welfare reform, the result of which is that young people will have their benefits reduced. The third factor is cuts to housing support services and social housing. The fourth factor is diminished 
access to owner--occupation, which has been caused by rising home prices and stagnant salaries, a reduction in loan-to-value ratios, and a reduction in mortgage lending. The fifth factor is changes in higher education funding structures, which leaves UK students an average of $18--20 \mathrm{k}$ of debt (Clapham et al., 2014, p. 2021). The last factor contributing to contextual changes is the rapid growth in demand for the private rentals. In the UK demand for rentals increased from 9.4 percent to 16.5 percent between 2000 to 2010 . The authors (2014) point out that with owner-..occupation inaccessible and social housing on the decline, the private rental sector will continue to grow with little regulation concerning housing security, basic standards, or affordability (p. 2022).

Clapham, Mackie, Orford, Thomas, and Buckley (2014) explore nine housing pathways for young people in the UK. Clapham (2005) defines 'housing pathways' as "patterns of interaction (practices) concerning house and home, over time and space" (p. 27). This concept was developed from the concepts of housing histories and housing careers (Clapham et al, 2014, p. 2017). A housing history focuses on what people did in the past to reach the present-a housing career assumes an upward trajectory over time. Housing pathways look back in time and use that information to make predictions about the future. Pathways address general trends as well as individual resources, preferences, and past decisions.

One example of a housing pathways is staying at home until one has saved up enough money to access homeownership. Many young people are willing to accept the stigma of living at home rather than paying for an expensive rental. Clapham, Mackie, Orford, Thomas, and Buckley (2014) predict that this pathway will increase and that the 
amount of young people buying homes will decrease (p. 2023). However, the authors (2014) find that most interviewees preferred to pay more of their income towards a nicer space and lifestyle rather than rent cheaply and save for a deposit (p. 2023). The authors (2014) point out that the same external factors will impact individuals differently, "Also it is evident that the general context will impact differently on young people with different resources and preferences, meaning that there could be substantial variations in the pathways that young people take over time" (p. 2017). Clapham, Mackie, Orford, Thomas, and Buckley (2014) analyze the housing pathways of young people using qualitative and quantitative data-they develop 'housing drivers' from their interviews, which are the factors that spur individual decisions, "...the use of qualitative methods can allow the use of attitudes, perceptions, and aspirations to understand the meanings attached by the young people themselves to the different categories" (p. 2018). Millennials attach attitudes, perceptions, and meanings to their housing pathways and economic situations-through qualitative data we can form those connections and find those meanings. In Clapham's study the authors investigate how the aspirations of young people interact with constraints to affect individuals' housing pathways. My thesis uses a similar structure since it looks at the external factors affecting Millennials financial decision-making. Later in this paper I compare the two structures. Clapham's concept of housing pathways is applicable to my research and I use his concept to describe the end result of Millennials financialplanning decisions. 


\section{Class and Race}

It is commonly thought that young people are good at embracing change. However, Colic--Peisker and Johnson (2012) write, "Being young is not enough to be able to smoothly navigate the liquid life; despite young people being the most adaptable to the changing social reality around them, one's class, or position in the socio-economic structure, remains a crucial determinant of the available opportunities" (p. 730). The authors argue that higher education teaches young people how to adapt to changethey aren't naturally adaptable. Young people can only adapt to their changing world when they have the knowledge of how to do so and opportunities in reach. For this study, the authors define class as educational attainment, family social capital, and family financial capital. Colic-.Peisker and Johnson (2012) find that both lower class and upper class young Australians have aspirations to own homes, but their strategies for getting there and their articulations of it are different,

For the disadvantaged young adults more choice translates primarily into more uncertainty, and, as a consequence, a retreat into old, established orthodoxies. For middle-class young people the choice and dynamism of the liquid life may indeed mean an array of opportunities that they can creatively exploit to achieve their goals (p. 738)

More advantaged young people took their experiences of housing stability for granted so they focused on the more abstract aspect of homeownership-status, exchange value, and its role as a wealth accumulation tool. Lower-income interviewees focused on the more practical value of a home as a stable place.

Bauman (2007) has characterized the phenomenon of things changing rapidly as 'liquid times' or 'liquid modernity'. Our global and inter--connected world is 
characterized by change. Bauman (2007) points out that the key to success is being able to learn quickly, which he argues is a privilege of the wealthy. Colic--Peisker and Johnson (2012) quote Sennett, “In Sennett's (1998: 30) words, relentless change can mean 'just drifting' for both groups; for the well--off an 'emotional and ethical' drift through an individualistic and competitive world; for the underprivileged an economic and social drift" (p. 741).

Hamnett (1999) shows that the housing market increases class differenceshigher income households gained almost twice as much as lower--income households from homeownership, due to the former's ability to trade up. Homeownership can function as a tool for class differentiation (Ronald 2008). In addition, as housing prices have risen, access to ownership has become more limited and housing has become a key determinant of wealth accumulation, making it increasingly detrimental to be excluded from this market (Malpass 2006).

A 2013 study from the Institute on Assets and Social Policy tracked the same households over 25 years, finding that the total wealth gap between White and African American households nearly tripled from 1984 to 2009 (\$85,000 to $\$ 236,500)$. The most significant contributing factor they found was years of homeownership. Owning a home leads to wealth accumulation in the United States, and African American households have been shut out from homeownership, preventing them from accumulating wealth at the same rate as white households.

There is an extensive literature on racist practices in the housing industry that have prevented African American individuals and households from accumulating wealth 
and equity. Women and people of color have historically been excluded from property ownership in the United States. In the United States, property ownership is the equivalent of citizenship, freedom and individualism. Homeownership plays a role in structuring and exacerbating inequality and an imbalance of political power (Ronald, 2008 , p. 20). UK housing scholar James Gregory (2016) says that property ownership is accompanied by self--respect and increased respect from others. It creates a "virtuous sense of independence" and has a "transformative effect on the individual's self-worth because of the greater control it gives them over their life" (p. 8). People of color and African Americans in particular have experienced discrimination in the housing market for decades, affecting wealth accumulation that can be passed down between generations as well as individual self-efficacy. Millennials are the most diverse generation yet, thus discussions of racism and equal access to homeownership are more necessary and pertinent than ever.

\section{Financial Literacy}

Real estate is arguably one of the most difficult industries to understand; yet the U.S. residential real estate market is worth 25.7 trillion dollars (Rascoff and Humphries, 2015, p. 21). The authors of ZillowTalk call the real estate market, “...an industry that seemingly everyone cares about, but virtually no one fully understands" (Rascoff and Humphries, 2015, p. 14). A recent Zillow survey found that Americans spend an average of 5 hours researching their mortgage options. Nearly one third of Americans spend 2 hours or less. In comparison, Americans spend an average of 10 hours of research 
before buying a car, and 5 hours researching their next vacation (Rascoff and Humphries, 2015, p. 74). Harris (2017) says that recent changes in the buying process and general lack of knowledge make the buying process confusing and unapproachable to young buyers. Big questions for young buyers include how much money to save, what kind of loans and mortgages you qualify for, and what happens at the end of the process (Harris 2017).

The private banking and financial planning industries are currently adjusting their products and marketing strategies in order to attract Millennials. A recent USA Today article points out that many Millennials who are seeking professional financial planning advice are going to advisers who understand the needs of this younger generation. The article says that Millennials are likely to have multiple jobs over their lifetime and are more inclined to rent than to own (Jones 2015). These factors, in addition to high amounts of student debt, mean that the financial strategies employed by Millennials' parents will not work for Millennials themselves. Experiencing the fallout of the Great Recession has shown young people that the economy has changed, and therefore planning for the future also needs to change. One professional financial planner in this article comments that housing decisions are not just about mortgage versus rent. For the Millennial generation, homeownership is not a given. Millennials will be looking for affordable investment options and creative solutions when planning for retirement (Jones 2015).

In 2015 iQuantifi did a report in conjunction with Middle Tennessee State University on the mindset Millennials have towards money. This report emphasizes that 
despite popular beliefs to the contrary, Millennials do have financial goals, however they don't know where to turn for advice. This iQuantifi report is based on a random survey of 500 Americans between the age of 21 and 35 in 2015 . The survey found that 72 percent of participants have financial goals. To 'increase the overall amount of savings' was the top goal for 2015 . Subsequent goals were to pay down credit card debt, save for a house, save for a vacation, save for retirement, buy a car, and save for a large purchase. The report also found that 37 percent of participants have mortgages. The average debt is $\$ 47,689$ and debt increases with age. 31 percent have studentloans.

The biggest challenges cited were making enough money, staying on budget, managing debt, understanding where/how to invest, and developing a financial plan. Lastly, 50 percent of participants get their financial advice from family.

This literature review discussed the economic factors that are affecting Millennials' financial standing and ability to buy homes. To provide insights on how individual Millennials are reacting to these economic factors I interview twenty participants. The interviews take place in Los Angeles, California. The next section describes the specific challenges facing Millennials in Los Angeles regarding homeownership. 


\section{Chapter 3}

\section{Los Angeles Context}

Below are some brief statistics regarding the housing market in Los Angeles:

- The median home value in Los Angeles County hit $\$ 609,562$ was April 2018 (Zillow 2018)

- The median home price in 2018 is $\$ 585,000$ (Chiland 2018)

- The salary required to afford (less than $30 \%$ ) that median price is

- $\$ 111,730$ (Chiland 2018)

- 75 percent of LA county residents don't earn that much (Chiland 2018)

- Across all of Southern California monthly mortgage payments rose $12 \%$ over the last year (Chiland 2018)

- Across Southern California home prices are $14.3 \%$ below prices of pre--recession peak (Chiland 2018)

- In Los Angeles county 40 percent of homes sell over the asking price (Chiland 2018)

- Supply is constricted-last year the number of homes for sale in LA county declined $22.8 \%$, and it was already below average (Chiland 2018)

Currently only 30 percent of Californians own homes. Downtown LA zip code 90012

is the 2 nd fastest growing zip code in the nation with an 8.8 percent population growth from last year (GordCollins). Because California developers are having difficulty meeting the demands of the continually growing population, housing prices are expected to keep rising for the next four years. Housing demand remains high and results in "all cash bidding wars" in some cases.

The buying power of Millennials is currently quite low. That may change in the next ten years as baby boomers pass their wealth down to their children. However, baby boomers are still driving growth in the housing market, rather than Millennials. The supply of affordable homes in Los Angeles is almost nonexistent and so Millennials are living with roommates and parents longer, rather than attempting to buy. According to 
the Census Bureau, 41.5 percent of Millennials in the greater Los Angeles area live at home or have moved back in with their parents (Romero 2017). In fact, renting is so expensive that Millennials would have to spend about 97 percent of their median monthly income just to get into a median--priced, one--bedroom unit in Los Angeles. Only Washington, D.C. had a higher demand on Millennial income (110 percent) for one-bedroom renters (Romero 2017).

Many interview participants pointed out that there are many other places to live in the United States where housing is more affordable. Yet Millennials flock to expensive urban centers and young people will likely continue to do so for generations. The discipline of economic development includes location, regional growth, and local development theories. Applying these theories to my case study of Los Angeles is beyond the scope of this thesis. However, it is important to note that these theories could shed light on why Los Angeles is so populated and expensive, particularly through the concept of agglomeration economies.

Urban economics scholars Edward L. Glaeser and Joshua D. Gottlieb (2009) explore why dense areas are so productive. The agglomeration of economies results in the pooling of labor, the flow of ideas, and reduced transportation costs. These are all reasons why proximity, meaning cities, are productive places. Los Angeles has so many concentrated industries, as well as so much concentrated human capital and labor pooling that firms and people come here. The high cost of housing is a result of people coming here to benefit from the agglomeration economies. In addition to the economic opportunities in Los Angeles, the culture, people, and lifestyle here are other factors 
that might appeal to more educated and middle to upper class Millennials. Los Angeles does provide a range of economic opportunities, but it is also costly to live here-those who are paid lower salaries struggle. People come here because of what they could achieve, however in reality Angelinos face the high cost of living, segregation, low wages, and basic survival. Like most capitalist cities, Los Angeles is a great place to have money and not great place to not have money. 


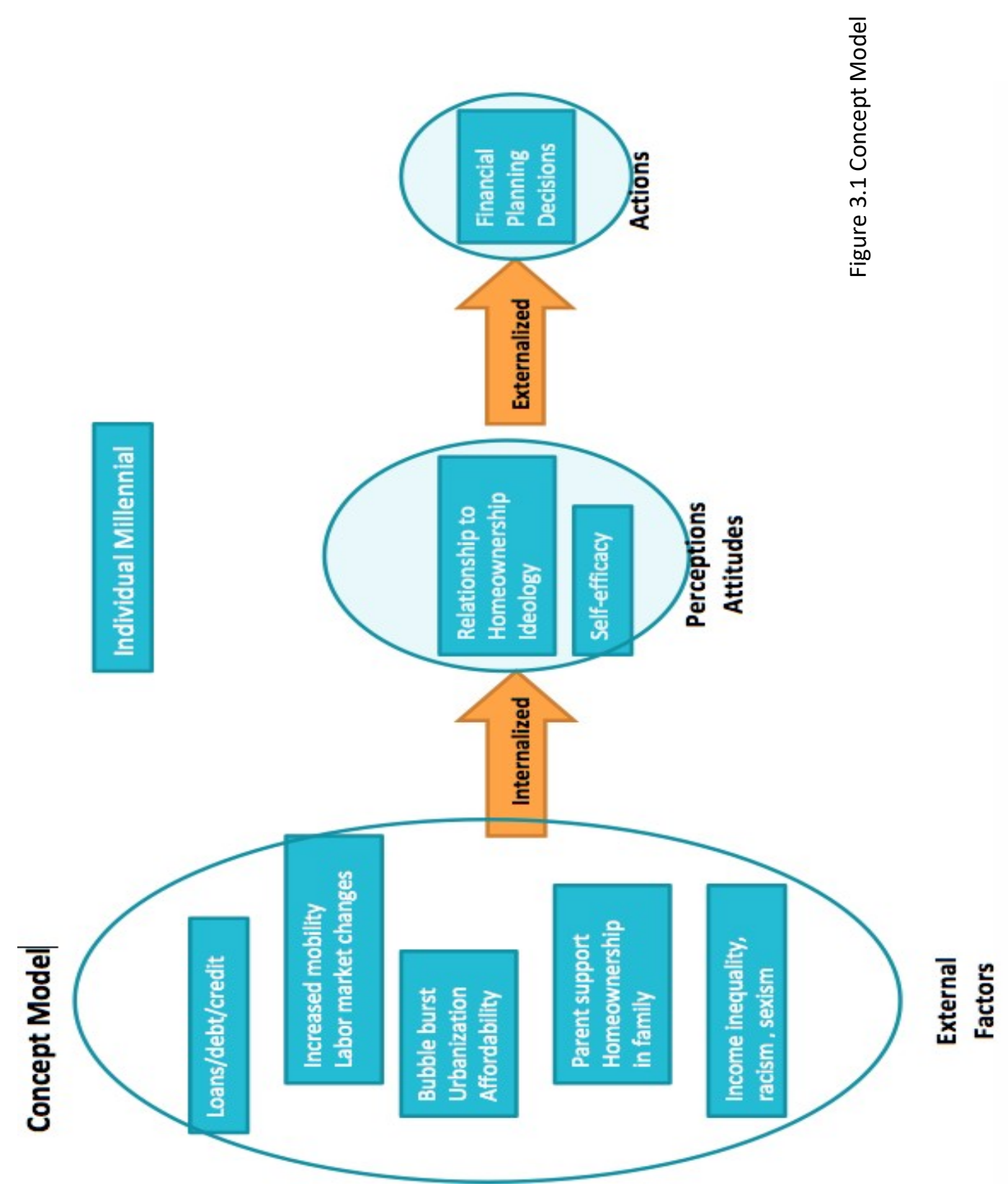




\section{Concept Model}

One of the primary arguments in this master's thesis is that the macro--level economic and social changes that have occurred in the past few decades affect Millennials on an individual level. These economic and social changes have been summarized in the literature review. Figure 3.1 is a concept model that illustrates the structure I use to approach my interviews and the concepts that I am using in this thesis. The concept model illustrates how the individual Millennial might process and react to the aforementioned external economic factors.

My concept model begins on the left with six external factors that are important in forming an individual's attitude towards homeownership as well as their personal sense of self-efficacy. The two items in the center of the concept model are the vehicle through which these external factors are processed. The box on the right is financial planning decisions - this is the dependent variable affected by the inputs on the left. Since creating my concept model I have added the concept of housing pathways to my thesis. The inputs plus the financial planning decisions all result in housing pathways - the concept model represents the process that determines an individual's housing pathway. This concept model investigates how external factors are processed internally into perceptions/attitudes and then expressed externally in the form of action. I use this concept model to guide my interviews and to provide a framework with which to understand their responses and then predict their housing pathways.

In the literature review I discussed Clapham's (2014) paper on housing 
pathways. Because his concept model is similar to mine I compare them in this section. Clapham's housing pathways approach highlights the importance of the interaction between choices and actions and the context in which they are made (p. 2028). The pathway of the individual is the result of the interaction between choice, action, and context. In the concept model I created for this thesis, I theorized that external economic factors influence the individual's attitudes, and then the attitudes inform actions. If I turned my linear theory into a circular one then economic factors, attitudes, and actions would all result in a housing pathway. Therefore, both my concept model and Clapham's model are similar. They both argue that economic factors/context, attitudes/choices, and actions are the contributing factors that determine housing pathways. They also both argue that the economic and social context young people are in right now presents major obstacles and constraints to homeownership. Below I use flow charts to compare the structures of my concept model and Clapham's model. 


\section{Concept Model Structure}

\section{External Factors \\ $\downarrow$ \\ Perceptions/Attitudes \\ $\downarrow$ \\ Actions \\ Financial Decisions}

Figure 3.2 Concept Model Structure

\section{Clapham's Structure}

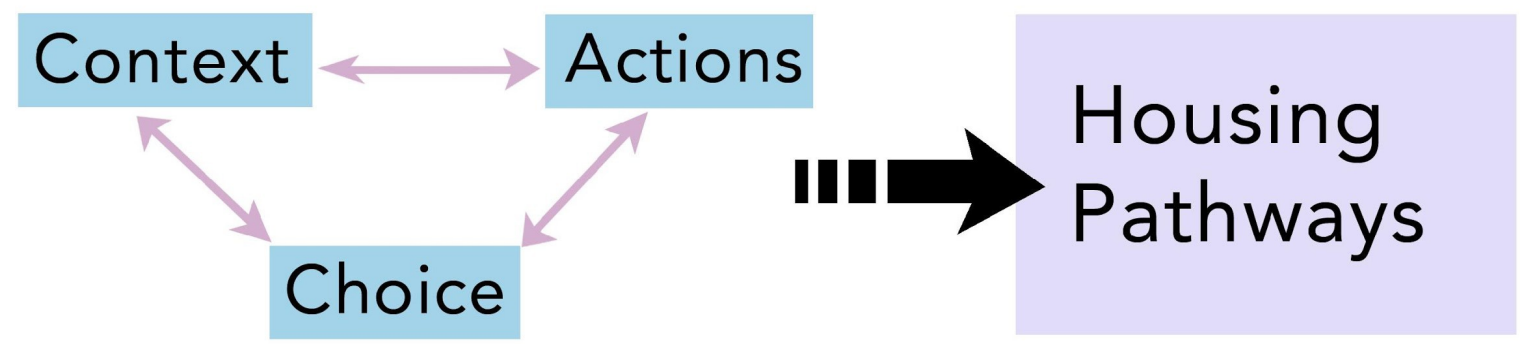

Figure 3.3 Clapham's Structure 


\section{Chapter 4 Methodology}

\section{Research Design}

Braun and Clarke (2006) emphasize the importance of a clear and explicit research design, "What is important is that the theoretical framework and methods match what the researcher wants to know, and that they acknowledge these decisions, and recognize them as decisions" (p. 80). This section outlines my research design, which includes the following facets: philosophical stance, research method, description of participants, and positionality.

Social constructivism is the philosophical stance used in this study. This study employs thematic analysis as its research method. Twenty in--person interviews provide the data for this study. The data is coded using ATLAS.ti. This study seeks to identify themes in personal narratives that will highlight certain experiences relatable to college...educated, middle to upper class Millennials in Los Angeles. Lastly, this study will construct a thematic map regarding Millennials' navigation of homeownership in Los Angeles. Below is an image that summarizes my research design: 


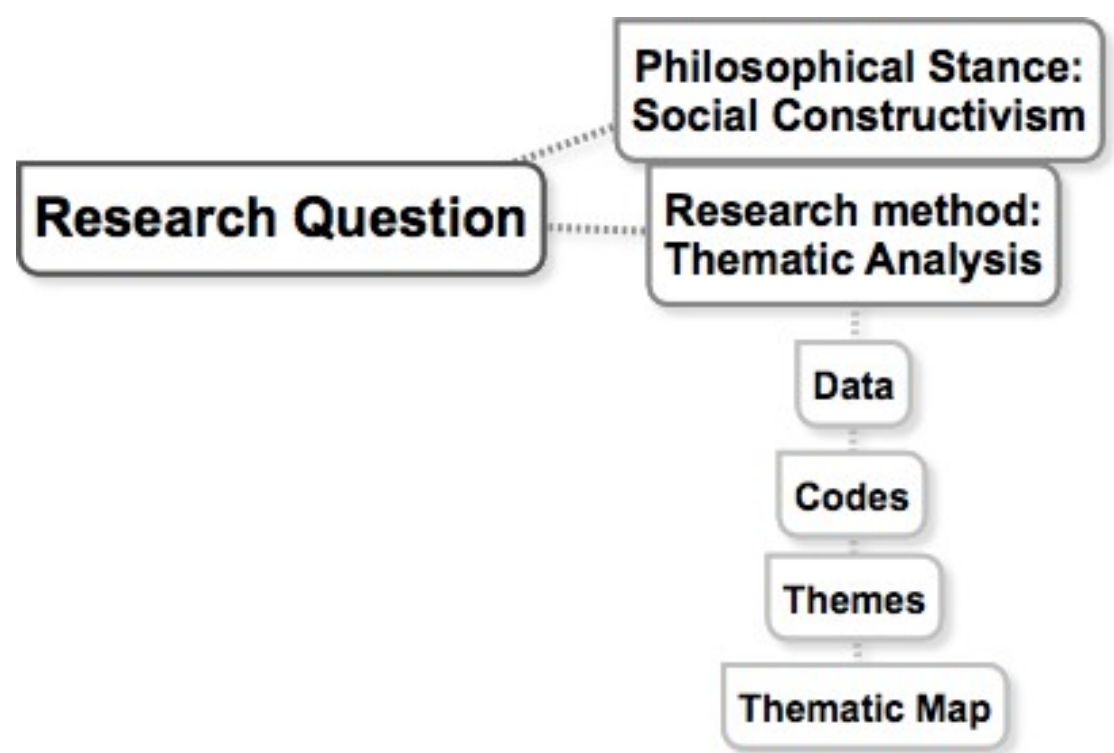

Figure 4.1 Research Design Structure

John Creswell (2003) calls social constructivism a 'knowledge claim position' (p. 6).

Other knowledge claim positions are post positivism, advocacy/participatory, and pragmatism-each position has different assumptions about how to produce knowledge and each lead to a different result. Creswell (2003) writes that social constructivism assumes that the individuals seek understanding of the world around them and that they develop subjective meanings for their experiences (p. 8).

Interview questions are open ended so that participants can construct complex meanings for situations and experiences as they discuss them with the researcher. Creswell (2003) writes, "Often these subjective meanings or negotiated socially and historically. In other words, they are not simply imprinted on individuals but are formed through interactions with others and through historical and cultural norms that operate 
in individuals' lives" (p. 8). Creswell (2003) also notes that constructivist researchers typically focus on,

The specific contexts in which people live and work in order to understand the historical and cultural settings of the participants...the researcher's intent, then, is to make sense of (or interpret) the meanings others have about the world.... Rather than starting with a theory (as in post positivism) inquirers generate or inductively develop a theory or pattern of meaning (p. 8).

Per Creswell, my social constructivist philosophical stance leads me to study the complex meanings that participants assign to their experiences in order to understand the historical/social/cultural contexts that shape their experiences and meaning-. making processes. As I interview participants about their attitudes and perceptions, I will identify the perceptions they have based on their experiences. My assumption is that individuals seek understanding of the world around them and that they develop subjective meanings of their experiences that are negotiated socially and historically. I assume that the knowledge I am looking for is within my participant's narration of his or her own experiences and thoughts. In the interviews I ask a variety of open-ended and specific interview questions in order to obtain data that is reflective of my participants' worldview. The data from the interviews serves to offer personal opinions and interpretations of the larger data on Millennial housing trends.

As previously stated, this study employs thematic analysis as its research method. Thematic analysis is a method for identifying, analyzing, and reporting patterns and themes across data sets (Braun and Clarke, 2006, p. 79). The key aspect of thematic analysis is that it allows the researcher to identify patterns of meaning across a variety of datasets rather than simply within a single dataset (Creswell, 1998, p. 57). Other 
qualitative approaches such as Interpretive Phenomenological Analysis (IPA) construct meaning from an individual's experience and thus the findings are unique to only that individual. Using thematic analysis will allow me to identity patterns across my sample of participants so that I can generalize my results to the larger group of people who have the same characteristics of that sample. Braun and Clarke (2006) point out that when researchers describe their process as themes 'emerging' it sounds like a passive account of what happened, which obscures the agency the researcher had in identifying, selecting, and reporting those themes. In reality coding and performing thematic analysis is very active and intentional, and researchers need to be explicit about what decisions and assumptions they make (p. 80).

Braun and Clarke (2013) explain that a lot of qualitative analysis is in fact thematic analysis, but it isn't labeled as that-it is often unlabeled or called content analysis. UK health sciences professor Mojtaba Vaismoradi and his coauthors (2013) write "Qualitative approaches share a similar goal in that they seek to arrive at an understanding of a particular phenomenon from the perspective of those experiencing it” (p. 398). However, there are differences between various qualitative research methods; in this section I explain why I use thematic analysis as opposed to a similar approach, content analysis. Thematic analysis emphasizes context whereas content analysis can overlook context. Vaismoradi et al (2013) write,

Certainly, content analysis makes sense of what is mediated between people including textual matter, symbols, messages, information, mass--media content, and technology supported social interactions.... On the other hand, thematic analysis is able to offer the systematic element characteristic of content analysis, and also permits the researcher to combine analysis of their meaning within their particular context (p. 399). 
Thematic analysis will best answer my research question because it considers context within the data analysis process.

Content analysis focuses on finding patterns and frequencies of language in a large dataset--it tends to be more quantitative than thematic analysis and focuses on the structure and discourses of communication. Content analysis produces categories whereas thematic analysis produces themes. The importance of a theme depends not on quantifiable measures but whether it captures some meaning within the dataset in relation to the research question $(2013,403)$. Graneheim and Lundman write in their article on content analysis, "A pragmatic way to state the difference between a theme and a category is that the latter refers mainly to a descriptive level of content and can thus be seen as an expression of the manifest content of the text, whilst the former is the expression of the latent content" $(2004,106)$. Content analysis focuses more on manifest rather than latent content. It creates themes based on the frequency of categories and assigns categories importance based on frequency $(2013,403)$.

Thematic analysis incorporates both latent and manifest so that the analysis of the manifest content automatically includes analysis of the latent content $(2013,403)$.

\section{Data Collection}

My participants are college educated, middle or upper middle--.class Millennials living in the Los Angeles metro area, the majority of whom have parents who own homes. The group of people I interview could be considered as part of the privileged and entitled Millennials who spend money on avocado toast yet struggle to make rent 
payments. The research process is informed by the researcher's identity and experiences. Thorne (2008) writes, "Text processing is understood as interaction between reader and text, as active construction of meaning structures by the reader. His or her pre--knowledge and interests have a selective and organizing function within this process" (p. 34). My positionality as a white, educated, upper middle-..class female affects what people I am connected to and the demographics of my social network in Los Angeles. In general, my social network consists of people with similar political opinions, similar race, similar class, and similar family and educational backgrounds.

Therefore, the sample size of 20 is a sample size of my particular social network in Los Angeles rather than a sample size that is representative of the actual population of Los Angeles. If it had been representative of the population it would be have been a diverse sample size because Los Angeles is a very diverse metro area. My sample size is not very diverse in terms of the demographics factors I just mentioned, however within this subset of privileged Millennials there was a surprising range of experiences and perspectives.

Quick facts:

- 5 percent African American

- 10 percent Hispanic/Latino

- 10 percent Asian

- 35 percent women, 65 percent men

- 35 percent first generation

- 10 percent international

○ 25 percent still in school

○ Age range: $23-32,9$ years

- 30 percent people of color/minorities, 70 percent white

○ 40 percent white males, 60 percent not white males 
- All participants except for one are college educated or currently in college

o 12 participants have student debt

- All participants' parents own homes except for 2

My positionality also informed what questions I asked participants, what I noticed about my data, and how I interpreted my data. In order to collect the data that will answer my research questions I will interview twenty individuals. I am using first-- hand interview data for this project since interviews provide detailed and nuanced data. There is not a large amount of secondary data on Millennial attitudes towards homeownership that includes the individual's experiences and ties this information to financial decision-making, however there have been several similar studies that were noted in the literature review. My unit of analysis is the individual. My access strategy is my social network in Los Angeles and my recruitment occurs through a snowball strategy of asking friends of friends to participate. Confounding variables are getting in touch with people and scheduling times to meet, as well the driving distance.

My research questions inform the content of my study and thus the questions I ask my participants. My research questions will help me focus on specific content in my interviews however when I look through the data a variety of expected or unexpected themes might emerge. The interview questions are listed in Appendix A. My research questions are: how have economic factors shaped Millennials' attitudes towards homeownership and their feelings of personal empowerment to achieve their own financial goals? How do Millennials' attitudes towards homeownership affect their financial decisions? 


\section{Data Analysis}

Braun and Clarke's (2006) version of thematic analysis includes the following steps: transcribing, initial coding, finding potential themes, solidifying themes, creating a thematic map, and producing a report (p. 87). The first step for the researcher is to start transcribing the interviews and thus familiarizing themselves with the data. I chose to transcribe my interviews per the rules of 'pure verbatim protocol', which Thorne (2014) defines as, "the transcription is done word for word including every utterance from the audio file. Dialect formulations, fillers, articulation are maintained. The transcript now is very near to the natural language..." (p. 45). I chose this protocol in order to understand not only the subject matter but the implicit emotional state of the participant.

Transcribing twenty interviews was a lengthy and tedious process, however it allowed me to familiarize myself with the content of the data. As I transcribed the interviews I noticed common topics and ideas appear in the interviewee responses to my questions. After the transcriptions were completed, I uploaded the data into ATLAS.ti and started my coding process.

The next data analysis step is initial coding. During initial coding the researcher determines the analytic significance of the data, fragment by fragment (Charmaz, 2008, p. 42). Kathy Charmaz (2008) says coding creates the bones of your analysis and assigning theoretical categories creates an analytical framework (p. 46). Charmaz (2008) puts things simply, "we create our codes by defining what we see in the data" (46). As mentioned earlier, Braun and Clarke (2006) point out that when we do not know 
the researcher's assumptions or decisions it is difficult to evaluate the validity of their findings or compare the findings to similar studies (p. 80). Charmaz (2008) advises researchers to study their hidden assumptions, as well as participants' hidden assumptions, so that when we are coding we can extricate actions and processes from assumptions (p. 47). The words that participants use reflect their personal values and assumptions, while my interpretation of those words reflects my own assumptions.

I performed the initial coding on each document before moving onto the next stage of analysis. During this initial coding I went over the text line by line and attached a summarizing phrase to each line or several lines. This code sums up what the section of text is communicating. This process does not include much interpretation; it is mostly observing and recording what is in the data. It includes my implicit assumptions regarding what the data is saying-my assumptions are largely affected by the context of my study and my positionality.

The codes imply what is important about the data and they determine which parts of the data will be counted and emphasized. As I performed the initial coding I did start to get ideas for common themes. As I assigned codes to the text I added some interpretive comments that I circled back to after the coding process. Some interviews produced many codes and some produced few; the range of quotations per interview was 18 to 87 . There were 20 documents, 811 quotations, and 1020 codes. The codes that I used most often were 'benefits of homeownership' and 'labor market changes'. 
After initial coding the next step is searching for and developing potential themes. Developing themes involves identifying key concepts and their relationships with each other. The idea is to identify concepts that are relevant to the research question and create interpretive themes around these concepts. This step entails bringing together codes that cover similar topics and ideas.

I used the code manager tool in ATLAS.ti to export all of my codes into Microsoft Excel. In Excel I searched and grouped codes by keyword. After I created a group I copied that group of codes and pasted it into a Microsoft Word document. In this document I outlined the codes into major and minor themes. I based my categorizing on content related to my research questions. I did not include 32 of the 1020 codes because they were not relevant to my research questions. I ensured that all relevant codes had been assigned to themes. Braun and Clarke (2008) define this research phase as "starting to analyses your codes and consider how different codes may combine to form overarching themes" (p. 89).

The next step of reviewing themes entails checking if the themes work with the coded extracts, the entire data set, and the research questions. Braun and Clark write that a theme, "...captures something important about data in relation to the research question and represents some level of response pattern or meaning within the data set" $(2006,82)$. I have major and minor themes laid out in Microsoft Word. I reviewed those themes and continued to refine them according the Braun and Clarke's guidelines. The minor themes are the aspects of the major themes that I want to highlight. I attached interpretive descriptions to the themes. In this step I also reviewed 
the data extracts or quotations from each code to make sure they collate into cohesive themes. After reworking the themes through several iterations in relation to the codes I reviewed the themes in relation to the entire data set. To do this I reread the entire data set. Braun and Clarke (2006) write, "At the end of this phase [reviewing themes], you should havea fairly good idea of what your different themes are, how they fit together, and the overall story they tell about the data" (p. 92). This step also includes developing a thematic map. The thematic map is then refined as the themes are refined.

The next data analysis step is to define and solidify themes; this mainly entails generating definitions and names for each theme. Braun and Clarke (2012) say that a good theme will have a singular focus, will directly address the research question, and not overlap but relate to other themes (p. 66). Once the themes are labeled and solidified the thematic map can be completed.

The next step is completing the thematic map. In this step I connect the themes in ways that show the relationships and processes between them. I did this by writing down the titles of my themes on small pieces of paper and spreading them out on a flat surface. I then arranged the themes in small clusters and this became my thematic map. Some themes were actually sub themes or shoot offs and others were primary themes. The mapping process helped me to determine how important each theme was based on its influence on the other themes. The themes that carried a lot of influence and that overlapped the most with other themes I placed in the center of clusters and then I put the less influential themes around them. After arranging my paper thematic 
map, I created a digital version, which is in the Findings section. 


\section{Chapter 5: Findings}

For some topics the twenty participants separately reached consensus, while on other topics participants voiced a wide variety of views. The themes that I found address the subject content that was discussed in my literature review. Below I describe each significant theme that I found in my data and its correlating minor themes. The following section provides a visual representation of these themes on a thematicmap.

\section{American Dream}

I asked each participant, 'what thoughts and images come to your mind when you hear the phrase 'American Dream'?'. I asked this question in order to explore the participants' political and social ideas that they attach to homeownership. In addition, the American dream addresses preferences and upward mobility, which are two key topics in this thesis. When asked to describe the American dream one participant said the following,

I think of a narrative that's been pushed in order to make us accept a really broken system in the foolish hope that every single person can achieve economic stability and physical safety. When I hear American dream, I think of the lie that the American dream is a real thing for all people and I think about systems of oppression like class, race, sex, and gender that actively work to decrease people's access to the American dream, but still depict it in a way that makes it seem like a possibility worthy of dedicating our life and tolerating a lot of abuse in order to try to achieve (Participant 18).

In contrast, when asked the exact same question, another participant said, "Having a big mansion in the Malibu hills overlooking the beach and possibly overlooking the city 
and 5 bedrooms you know having a beautiful wife having two or three kids and a stable job that's the American dream for me" (Participant 17). Some participants viewed the American dream as a problematic narrative that perpetuates systems of oppression. Other participants saw the American dream as a motivating ideal or goal that positively affects society. However, most participants were critical of the American dream and saw it as a something negative. Participants criticized the old American dream, saying that people pursue something that is not satisfying. Many participants said that they felt like the American dream is sold as a lie. One participant points out that what everyone really wants is to be happy. The participant puts it this way,

I think it just plays into that narrative of once you get this you'll be satisfied you'll be happy and content but when you don't have that then you're striving for it you're getting in debt for it you're buying shit you can't afford to get it. You're taking out loans doing whatever you can you're working extra hours, but you could be spending that time and effort and energy on things that are actually present and satisfying and fulfilling (Participant 1).

A major theme that I found was that participants want to enjoy the present; they want a good quality of life now. They aren't willing to wait until retirement to enjoy life. Many participants said that their American dream was to make a living and to be able to enjoy life in the present moment. Several participants voiced that their American dream is to have the opportunity to work and attain a good quality of life but to have a work/life balance. Many participants felt that Millennials want to be more than just employees - they don't want to be chained to their jobs.

Most participants, when asked what the American dream was, said the classic white picket fence 1950s family life. Although they had that association, participants challenged and questioned that image of happiness and success. Many participants 
felt that Millennials believe in the American dream, but they define it differently.

Participants said that the new American dream is the freedom to go anywhere and do anything without oppression or judgment. One participant describes his American dream as,

In a nutshell it's simply the opportunity to go out there and pursue whatever it is that you want regardless of social stigmas such as race, gender, sexual orientation, etc. I think it's really the opportunity to pursue those dreams whatever they might be without those objections. For our generation I don't think the American dream is so much based on the physical assets I think that we are more so looking for personal fulfillment and to find that first you have to figure out what that looks like for yourself then you have to go find it (Participant 18).

A major theme was that the American dream is not one size fits all, it's about having the opportunity to be an individual and carve out your own path. This correlates to housing, since many participants voiced that they didn't want a typical house in the suburbs but rather the flexibility to choose whatever living situation fit their current lifestyle.

Almost half of the twenty participants have parents who moved from other countries to the United States. For participants whose parents emigrated from other countries, their parents placed great value on owning property in the United States and tended to equate property ownership with citizenship. Another prominent theme was that despite its flaws, the United States is still the land of opportunity. One participant put it this way,

Even if it means I'm going to have to work myself borderline to death that opportunity is still there as opposed to just being stuck like in a class system where you're born in a certain class and you can make more money than other people in that class but your still stuck in that class (Participant 7). 
A different participant emigrated to Los Angeles from another country and started a business here. He said that he is living his American dream and that living in the United States allows him to be creative and pursue his passions. To him, the United States represents the freedom to choose your own path and make a living doing that. Another international participant said that the United States still has the most opportunities of any country because of its specialization and access to technology.

\section{Los Angeles}

All twenty participants were interviewed in the Los Angeles metro area. I asked if they wanted to settle down in LA or someplace else. Participants explained that people love Los Angeles and are willing to pay a high price to live here. Participants know that it is a sacrifice to live here because of the housing prices, high cost of living, traffic, and crowds. A significant theme was that Millennials are choosing to live in LA even though they know it is not fiscally smart. Los Angeles is far from affordable, yet Millennials are willing to pay to be here because their priorities and goals outweigh the affordability issue. One participant made the point that he is not interested in living in the places in this country that are more affordable. Despite its logistical difficulties Los Angeles is just as popular as ever.

Conversely, some participants started to waver in their love for Los Angeles and they expressed how difficult it is to live here. Some participants said that it is possible to live the American dream elsewhere, but it is near impossible to live out in LA. In 
response to my asking whether Millennials in Los Angeles will manage to buy homes one participant said, "No I absolutely do not think they will be able to, this is specific to Los Angeles, but I think that the housing prices are so extreme that the vast majority of people who are interested in homeownership will not be able to attain that" (Participant 13).

Participants talked about how little house their money could buy here and how ridiculous it would be to try and buy a house in Los Angeles. The high cost of housing here definitely affects self-efficacy, housing pathways and financial decision-making. The primary theme regarding Los Angeles was that the high cost of housing significantly impacts every participant and the housing pathways that are available to them. One participant said the following about buying a home in LA, "I mean there are some people who are going to make it and there is a far greater population who is not going to make it" (Participant 5). All twenty participants complained about the cost of living in Los Angeles and the fact that incomes are not enough to cover current housing and education costs. All participants who wanted to own homes agreed that affordability was the biggest obstacle between them and homeownership.

\section{Financial Concerns}

I asked participants what they thought their biggest financial obstacle was, and many participants immediately mentioned student loans. Several themes emerged under the umbrella of student loans. The first is that they are preventing participants from saving money and moving forward financially. Student loans are likely 
contributing to Millennials buying homes later in life-one participant is on a 25-year repayment plan. Another theme is that student loans greatly reduce buying power, and they hurt credit scores. However, the most significant theme regarding student loans was that they are simply too high. One participant lamented the fact that his uncle attended college for 800 dollars a semester in the eighties. This participant attended USC, which costs approximately 25,000 dollars per semester.

Another related theme is that participants are debt averse. Many participants commented that Millennials don't like having debt and so it is very unlikely that they will take on a mortgage before paying down their student loans. Participants said that the combined debt of student loans and a mortgage would be overwhelming. One current student said,

Yeah it's so sad so I know for the next 10 years I'm going to be working and paying off my loans at the same time so unless I make a lot of money like a surplus of money that I can handle my loans easily I probably wouldn't even consider buying a home until my loans are paid off (Participant 16).

Student loans affect housing pathways since many participants pointed out that Millennials are living at home or with multiple roommates in order to save money so that they can pay down their loans. Lastly, participants pointed out that Millennials are the first generation to enter the labor market and housing market carrying significant amounts of student debt.

I found several themes regarding the labor market. Participants said that Millennials are waiting for baby boomers to retire and open up higher--level positions. Participants also said that technology has changed the labor market, causing everything to move at a quicker pace. Technology has both created jobs and made 
jobs obsolete. It has made working remotely a possibility, which many participants mentioned as a desirable situation since it can provide a solution to expensive housing. Another theme is that health insurance and retirement now come from employment, so participants depend on employment heavily. In addition, almost all participants said that their number one priority right now is career, and that most Millennials are focusing on career over everything else, simply because things are so competitive and expensive. Another theme is that jobs don't provide training, so employees have to absorb the cost of their own training and education. The last theme that I noticed in the interviews regarding the labor market is that participants complained about stagnating wages not keeping up with the high cost of living in Los Angeles.

A significant theme that I found throughout the interviews is that participants had moved frequently and expected to continue to move frequently. Most participants said that their number one priority at this time is career, and that they would move for career reasons. Participants' priorities were not to settle down but to make enough money to survive in this fast-paced economy. Changes in the labor market have contributed to this phenomenon. Homeownership makes less sense when you plan on moving. Even after marriage and family formation, career may still cause increased mobility for Millennials. One participant explains,

Yeah like every 3 or 4 years we are going to change our job, like I know people that have had jobs and then have tried to get recruited out of those jobs by companies that can pay them more and pay relocation fees and stuff. So honestly, I feel like it's really rare for people to be like I'm going to stay here and like get raises and get benefits (Participant 16). 
Lastly, wealthier Millennials often prioritize traveling and new experiences, which further increases mobility.

\section{Homeownership}

I asked participants what they thought were the primary benefits of homeownership. Common responses were freedom, stability, and building equity. Most participants saw the emotional benefits of having the freedom to make changes in your own home and the sense of security that comes with ownership. Another theme was that the primary meaning of home for participants was a stable 'home base'. Even those who were not inclined towards homeownership said that they thought having a reliable home would be a major benefit. Participants also saw the financial benefit to building equity as opposed to paying rent. Although most participants agreed on the benefits of homeownership there was a wide variety of attitudes and preferences in regard to homeownership. Attitudes ranged from zero desire to own a home to definitely wanting to own a home. Preferences ranged from wanting to buy land in a rural area to wanting to buy an apartment in an urban mixed..use area. There was a wide variety of preferences, however most participants expressed the desire to purchase a small, affordable home in a somewhat urban location.

Asking Millennials in Los Angeles about their thoughts on homeownership led to many pessimistic, frustrated, and ambivalent answers. Many participants expressed a thorough rejection of the traditional American dream and homeowner ideology as 
outdated and unrealistic. Additionally, many participants said that owning a home and owning things in general causes stress rather than peace of mind. A significant theme was that participants didn't want to be as stressed out as their parents. Many participants witnessed their parents work hard for decades and then lose large amounts of money in the Great Recession. Participants seemed hesitant to buy homes for a variety of reasons, however it seemed that the perception of homeownership as a stable and peaceful thing had changed for some participants.

Another more negative theme is that homeownership is not a possibility because of the cost. One participant says,

I think a lot of Millennials will want to buy homes, I think the vast majority of Millennials will not be able to buy homes and will be stuck in a renter situation for the rest of their life....unless the Millennial in question had money to start with that they got from their parents or something or who can get a really job I mean it' $d$ have to be a really good job most are unable like for most its [homeownership] going to be a non-option (Participant 7).

\section{Delayed Life Stages and Parents}

A well--known cultural trend is that Millennials are getting married and having kids later in life than previous generations. The period after school and before marriage is extended for many Millennials. Participants confirmed this trend and gave several reasons for why it is occurring. The reasons for delaying marriage were: to focus on personal development, marriage and kids is too much responsibility, it is taking longer to establish financial stability, it is taking longer to establish a career, and settling down is simply not a priority. There are many reasons for delaying family formation. Most participants voiced that whatever their personal reasons, they would be getting 
married much later than their parents did. However, most participants said that if and whenthey do settle down they would be interested in homeownership at that point.

One participants' story illustrates how financial support from parents makes a huge impact on financial stability and housing pathways. This participant's parents paid for her education and provided other forms of financial support. This is an example of class reproduction and the passing down of actual capital, social capital, and financial knowledge. Interestingly, this participant has no interest in homeownership and thinks that the stock market as opposed to real estate is a much easier and lucrative wealth-.-building tool.

The twenty participants had a wide range of experiences regarding parent support-some had significant support while some had no support. What was clear was that financial support from parents, particularly whether the parents covered college tuition costs or not, significantly affected the participants' current financial standing.

Financial support from parents also affected the housing pathways available to each participant. One participant pointed out that all of his friends who currently own homes had financial support from parents, and that's why they were able to buy those homes. He says,

It is interesting because my Millennial friends who do own homes not judging but when I think about why it's because they didn't pay for college and they lived at home they either lived at home right after school or worked remotely and one of them bought a house in Arizona because that's where he's from so he was working remotely he was saving money by working at his parent's house for a little bit and then the house he ends up buying was his wife's family and they sold to them for a good deal so my friends who own homes it's like you own a home because you had help (Participant 26). 
Almost all of the participants expressed that they thought their parents had an easier time achieving homeownership. The general consensus was that baby boomers had it easier when it came to housing prices, cost of living, pensions, cost of tuition, and the labor market. Many participants expressed frustration, resentment, and even blame towards baby boomers. Participants expressed that baby boomers don't understand how different the economy is now and how much more expensive things are now. Participants felt that baby boomers tend to think that Millennials are entitled and incompetent. One theme that emerged is that participants thought that baby boomers accepted the economic system and didn't ask questions because it benefited them. Now that Millennials are struggling with student loans, expensive housing, and a difficult labor market they question everything and are frustrated with these systems. Several participants expressed pride in being a Millennial because we question everything, and we initiate needed social movements.

\section{Retirement and Uncertainty}

An interesting theme is that participants didn't see homeownership as the only path to retirement. Several participants said that they preferred to invest in the stock market because the returns are higher. Many participants said that they saw the logic to building up equity in a home, but there are other ways to build equity. Many participants lamented the death of pensions and social security and said that things are much more uncertain now. One participant pointed out that in the United States the individual is responsible for his or her own retirement costs, 
It seems like places that don't have the wealth the US has find ways to take care of the older folks who don't have pension plans and 401ks and stuff it doesn't means that we shouldn't have a systemic way to take care of people who are elder but there are other things (Participant 8).

However, most participants saw retirement as a problem for their future selves and were focused on surviving and making rent payments in the present.

A significant theme that I found was that participants have too many options. They have all the information that exists at their fingertips, so when making decisions they can research all the options. This makes it harder to decide where to live, what to do, whom to marry, etc. Another related theme is that because they have so many options now participants were slow to make commitments. Participants expressed distaste for 30-year mortgages, saying that it doesn't make sense to make that commitment because life is uncertain and unpredictable. One participant puts it this way,

The American dream is a template for a lifestyle that was achievable in a different time with different economy and a different job market but now I think that a lot of Millennials' make goals that are more short-term and our long-term goals it would all be nice for us all to have a single-family home with a yard and a dog and 2 kids, but I don't think a lot of us think that's possible. I don't know if I'll ever get to own a property, I really hope I do and I want to save for one but I'm not sure what'll happen (Participant 10).

Another theme is anxiety over the future due to recent political unrest. One

participant says,

I'm trying to think of a way to say this without being overly melodramatic but political unrest as well because the way that a lot of things seeing to be changing so drastically back and force in our political sphere like the tax code is changing and I could be in a position where I had saved up a bunch of money and was ready to own a home and within a couple months I may not be able to do that (Participant 7). 


\section{Values}

One of the primary findings from my interviews was that Millennials are making financial decisions based on their values. One participant said that he would rather spend 300 thousand dollars on traveling over a house because the former would make him happier. Participants also expressed the value for experiences over things. Participants commented that baby boomers were more interested in physical assets and luxury goods whereas Millennials would rather spend their money on experiences.

The house is a visible status symbol and according to participants, it still has that function in society. However, one participant pointed out that rather than physical goods, some Millennials achieve status through visibility on social media, which often involves sharing experiences and trips. Status is important to every generation, however as values and preferences shift status symbols shift as well. The home may not hold as much status for Millennials as it did for baby boomers. This could affect the self-efficacy that Millennials feel in relation to homeownership. If homeownership is not a strong status symbol, then the inability to own a home may not be so personally disappointing. However, this conclusion requires further study.

One participant discussed the homeless population in Los Angeles, pointing out that many of them struggle with mental illness. He said that our cultural values make us completely focused on our own gain to where we ignore the plight of others. He thinks that if society had the value of community and responsibility for our neighbors that the homeless problem could be solved. He sees our housing issues as the result of 
society having certain values-namely profits over people. He says,

I think we have this culture in the US that's very individualistic like if you can't take care of yourself you're useless and valueless and pushed somewhere else and I think that happens to a lot of people.... there's a lot of little things that can be done but ultimately it's a cultural shift a personal shift (Participant 8).

Many participants expressed that our current economic system is unjust and that it perpetuates inequality. Many participants expressed that the values of our capitalist society don't align with their personal values. Their personal values focused more on freedom from oppression, social justice, community, and quality of life. When asked about values participants also expressed a desire to return to a local scale, as a reaction against globalization. One participant who is African American said that his parents' American dream was simply for life to be easier for him,

Yeah so my parents growing up in the like 70 s 80 s 90 s I think their American dream would've purely simply been I hope it's easier for my kids like as black parents they were doing everything they could to make their kids' lives were easier (Participant 19).

One participant has been unable to visit his family or have them come visit him because of the current administration. He is afraid to leave the country or travel by plane. This limits the housing pathways available to him.

\section{Government}

I found several themes when discussing the role of the government in homeownership and the current economic challenges that Millennials are facing. Both liberal and conservative participants thought that the government is not handling the 
housing crisis well. Liberal participants said that raising minimum wage doesn't help the problem and that corporations and the government are failing to provide affordable housing. There were only two participants who could be called 'conservative' and they thought that Millennials should be more responsible with their personal finances. To the contrary, a liberal participant said,

You get into this habit of like you can't make as much money as you're spending. You're spending on things that used to be so great like school. I think Millennials really are paying for that and there's no real solution that's been given to how to better manage finances it's like you can penny pinch you can do this or that all that money is not going into investments it's not going into retirement it's not going into a car it's not going into anything (Participant 19).

One of the conservative participants said that he used to believe in the trickle--down effect but after his company rebounded from the crash he didn't see any personal gains. He realized that the people at the top of his company were pocketing the gains themselves and not funneling them down.

\section{Alternative Housing Pathways/Models}

An interesting theme is the desire for a wider variety of housing options and models. Several participants expressed the desire to live in community land trusts or tiny homes. The consensus was that our current housing system simply isn't working. Some participants will pursue traditional housing pathways while some will look for other options. Many Millennials will likely look for creative options because of affordability and preferences for mobility and flexibility. One participant says,

I think you're going see a lot more creative pinteresty options, like people who 
are coming from a younger generation are going to have opportunities to build property and then you're going to start seeing buildings that are multi use almost like a duplex or quadplex and each one is its own individual unit and you can buy individual units as a part of this larger unit. That's just imagination spitballing. But you're going to see more creative things that you don't usually see that will change the way the housing market works (Participant 8).

\section{Self-"-Efficacy}

An additional finding was that there was a significant range in self-efficacy within the group of twenty participants. Some participants felt that their actions did produce results while others felt that there was nothing they could do to affect their housing pathways.

The participants I interviewed are all dealing with similar economic factors such as student loans, high cost of living, and an evolving labor market. However, despite their shared context there was a wide range of feeling empowered versus disempowered to achieve financial goals. It is difficult to determine what factors most strongly influence self-.efficacy, however because the participants are living in a very similar context, family background, financial standing, values, and attitudes are the factors most likely to influence self-efficacy.

The next three quotes are from three different participants expressing pessimism towards their ability to achieve their financial goals, I think that I don't know how realistically attainable that [homeownership] is but that's what my goal is. I know it's what I want I don't know if it's going to be a reality probably not in the next 10 years, but we'll see you never know (Participant 15).

I would love a house sooner rather than later but that's probably not going to happen in California (Participant 9). 
It feels like based on a lot of things like social security is running out all the different things I feel like I' $m$ in a position where the goal line is being constantly pulled away as I'm racing towards it (Participant 8).

These participants feel like they will not be able to achieve financial success regardless of their actions, and that success will always be unattainable because the system is stacked against them. These statements reflect very low self-efficacy. On the other hand, several participants were positive that they could achieve their financial goals. One participant said that on a scale of 1 to 10 , he was a 10 in confidence that he would one day own a home. He commented, "If I stick to what I'm doing and am willing to put in the time I think it's achievable".

\section{Thematic Map}

This section contains a thematic map, which is the final step in my data analysis process. It provides a visual representation of the themes I found in my interviews. The purpose of the thematic map is to highlight the relationships between the themes by placing them spatially on a chart. The map also highlights how the themes cluster together to form more significant themes.

The elements in my concept model are present in my thematic map. However, the thematic map and concept model represent different processes. The thematic map presents the subject content of the interviews and how the themes from the interviews shape housing pathways. It does not show the order of how the themes affect each other or how the individual navigates those themes. The concept model shows how the individual Millennial processes the content that is in the thematic map 
to result in housing pathways. The concept model does not include all of the subject content of the interviews, rather it maps out a decision.-making process. The thematic map shows that all of the themes are filtered through self-efficacy and then result in housing pathways, in this way it is similar to the concept model. The major difference between the thematic map and concept model is that the former shows the subject matter of my data while the latter shows the individual processing that subject matter. 


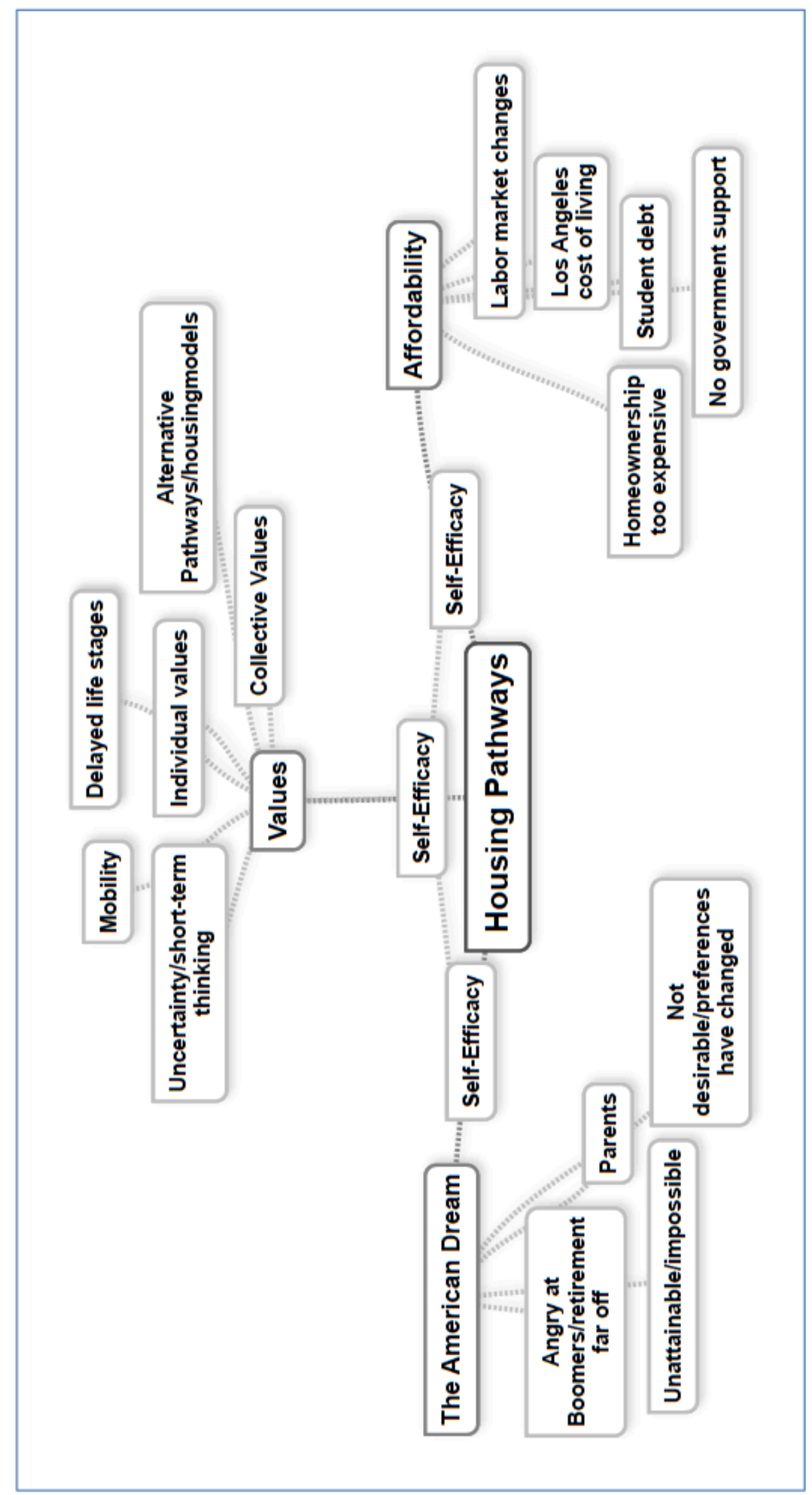

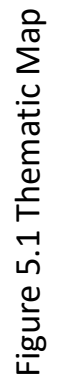


The thematic map shown above displays the themes that I found in my data. After completing the thematic map, I applied my concept model to four different participants. I chose four participants who have a variety of family backgrounds and attitudes towards housing. I filled in the structure of my concept model with their individual interview data. This process showed how the external factors discussed in the literature review affected the participants' self-efficacy and attitudes, and then their financial decisions and housing pathways.

Participant 8 grew up experiencing wealth and privilege. His experience living in low--income areas revealed to him the cracks in the system and now he rejects it completely-his housing choices and housing goals communicate that rejection very clearly. The external factors in his life shaped his values, which then informed his financial decisions and housing pathways. Participant 7 also grew up in a privileged setting and is currently very disillusioned with the economic reality he is facing as a young adult. He feels let down by the economy and by this country and he feels that the difficulties he faces are symptoms of a flawed system. Although he has a similar family background as Participant 8 , he is not seeking to change the system he is seeking to survive it. This shows a significant difference in self-efficacy.

Participant 19 has a different background than Participant 7, yet they have similar levels of self-efficacy. This could be because they are in similar financial situations. They both have student loans and they are both making just enough to cover their expenses. Both Participants 19 and 7 feel that the system is flawed and that if things were better they would be able to save money right now. They both feel that they are 
along for the ride and that there is not much they can do to change the course of their housing pathways.

Participant 20 has a stronger sense of self-efficacy than Participants 7 and 19, even though they are all experiencing a similar economic context. Participant 20 could have higher self-efficacy because he has a high salary and therefore is less affected by the economic context. His high salary also makes him more resilient to economic changes and upsets where as Participants 19 and 7 feel less secure. However, Participant 8 and 20 have the highest self-efficacy yet their financial situations are almost opposite while Participants 7 and 19 both have low self-efficacy and similar financial situations.

Both Participant 8 and 20 have medium to high self-efficacy, and they have similar family backgrounds and experiences. However, they have completely different reactions to the American dream narrative and have made divergent financial decisions and therefore have different housing pathways. Participants 19 and 7 have different family backgrounds yet they both have low self-efficacy and will likely have similar housing pathways. 


\section{Chapter 6: Discussion}

The primary themes I found through my interviews are the American dream, affordability, values, and self-.efficacy. These primary themes have the most influence and impact on the participants' housing pathways. Participants' perspectives on the American dream greatly impacted whether they wanted to buy a home and what types of homes they would be interested in. There was also a significant theme of the American dream changing and evolving into something completely different than our mainstream cultural narrative. This finding relates to my research question of how homeowner ideology (the American dream) affects Millennials' financial decisions.

The second theme I found was that values significantly affect housing pathways. I found that individual values influence financial decisions, for example the priority of traveling over settling down. I found that the participant's individual feelings of self-..efficacy and agency were affected by their values and priorities - because their values determined their financial goals. What is equated with success is changing, and that will affect self-.esteem and self-efficacy.

Many participants expressed frustration with their current financial situations and with the housing pathways available to them. Millennials will likely be the first generation in American history not to out--earn their parents. Many Millennials may be taking this fact as a personal failure, however most of my participants felt that the difficulty they faced in attaining a home was not their personal financial failure, but evidence of a broken economic system. The decreased self-efficacy that participants conveyed is due to the reality for their economic context, thus structural changes are necessary to restore morale 
and self-.efficacy to my participants and the wider cohort of middle to upper middle class, educated, and largely white Millennials. This theme addresses my research question of how self-efficacy affects financial decision-mmaking.

The third theme is affordability and addresses the practical reality that many people in urban areas struggle to make rent payments and on top of that save any money. This theme addresses the external economic factors that are creating a challenging context for all Millennials. This theme addresses my research question of what economic factors affect Millennials' attitudes towards homeownership.

In terms of housing pathways, there were a variety of current pathways and future aspirations within my group of twenty participants. For the participants who want to buy homes and who can afford to buy in Los Angeles, they will definitely buy in Los Angeles. For those who want to buy a home but cannot afford to buy in LosAngeles, they will move to a lower cost area in order to attain homeownership. For other participants, living in Los Angeles was a higher priority than homeownership and they will rent long term. For some participants neither homeownership nor living in Los Angeles was a priority. For these participants their housing pathways are very open--ended and unpredictable.

\section{Conclusion}

If housing prices do not decrease, then both buying and renting in urban areas will only be possible for the very wealthy. Gentrification will continue, and lower income 
populations will continue to be forced into commuting and absorbing increased transportation costs. The housing stock that is available for rent and purchase in American cities is important because it determines who gets to live where. If we do not provide affordable housing stock in our cities, then they will become increasingly segregated by race and class. We need more affordable starter homes so that Millennials of all backgrounds can start to build equity and participate in the housing market.

If homeownership does not become more accessible and affordable then upward mobility won't be attainable and the wealth gap in our country will widen. Many economists project that income inequality will increase and if we do not raise incomes for everyone then a very large portion of the population will struggle to get by. Gen Z, the generation below millennials, is the most diverse generation yet. In order to have a prosperous nation with a good quality of life for the majority of its residents then this country needs to change its housing and education systems to support young people of color rather than put obstacles in their way.

Young people today are stuck in a difficult economic situation and if politicians want to support young Americans then they need to make policy changes. My policy recommendations are that young people get into politics, we build affordable starter homes and affordable apartments with government assistance, we relax zoning so that people can build tiny homes and ADUs, we create more student debt forgiveness programs, and we reduce the cost of education. 
The primary takeaway from this master's thesis is that most Millennials do want homes, but they will have to buy them later in life due to economic constraints.

Additionally, unless the structure of the housing market changes or there is another bubble burst, the majority of Millennials in higher cost urban areas will not be able to buy homes at all and will have the rent indefinitely. Millennials will come up with different housing models and follow different housing pathways in expensive urban areas out of necessity more than preferenc 


\section{References}

Andrew, M. (2010). The Changing Route to Owner Occupation: The Impact of Student Debt. Housing Studies, 25(1), 39-62.

Bandura, A. (1997). Self-.Efficacy: The Exercise of Control. New York: W.H. Freeman and Company.

Bauman, Z. (2007). Liquid times. Cambridge: Polity.

Bourdieu, P. (2005). The Social Structures of the Economy. Cambridge, UK: Polity. Braun, V., \& Clarke, V. (2006). Using Thematic Analysis in Psychology. Qualitative Research in Psychology, 3(2), 77-101.

Braun, V., \& Clarke, V. (2012). Thematic Analysis. APA Handbook of Research Methods in Psychology, 2, 57-71.

Bylund, J. R., York, N., Xu, Y., Johnson, C., Bartholomae, S., O'Neill, B., ... Hoover, J. (2015). Homeownership Among Millennials: The Deferred American Dream? Third World Quarterly, 44(6), 1092-1109.

Chiland, E. (2018, January 17). One-third of LA homes sell above asking price. LA Curbed. Retrieved from https://la.curbed.com/2018/1/17/16897762/los-angeles-homes-asking-price--sales

Chiland, E. (2018, March 21). LA home prices shoot up 15k in February, hit new record. LA Curbed. https://la.curbed.com/2018/3/21/17147418/los--angeles--home--prices. -record--high

Chiland, E. (2018, April 24). Buying in LA has never been pricier. LA Curbed. https://la.curbed.com/2018/5/15/17358264/los-angeles--home-.prices--how-much-to-buy-income

Chiland, E. (2018, May 5). It takes a salary of over $\$ 100 \mathrm{k}$ to afford a typical home in LA. LA Curbed. Retrieved from https://la.curbed.com/2018/5/15/17358264/los-angeles-home--prices-how-much-to-buy-income

Clapham, D. (2005). The Meaning of Housing: A Pathways Approach. Bristol: Policy Press.

Clapham, D., Mackie, P., Orford, S., Thomas, I., \& Buckley, K. (2014). The housing pathways of young people in the UK. Environment and Planning A, 46(8), 20162031. 
Census of Housing. (2011). Historical Census of Housing Tables. Retrieved from census.gov. https://www.census.gov/hhes/www/housing/census/historic/owner.html

Colic-Peisker, V., \& Johnson, G. (2012). Liquid Life, Solid Homes: Young People, Class and Homeownership in Australia. Sociology, 46(4), 728-743.

Coyne, A. (2016, April 21). Millennials face home buying obstacles. The State. Retrieved from http://www.thestate.com/news/business/article73036342.html

Creswell, J. W. (1998). Qualitative inquiry and research design: Choosing among five traditions. Thousand Oaks, CA: Sage Publications.

Creswell, J. W. (2003). Research design: qualitative, quantitative, and mixed methods approaches. Thousand Oaks, CA: Sage Publications.

FindAid.org. (2015). Student Loan Debt Clock. Retrieved from http://www.finaid.org/loans/studentloandebtclock.phtml

GordCollins.com. (2018, March 8) Los Angeles Housing Market. Retrieved from https://gordcollins.com/real--estate/los-angeles-real-estate-forecast-2016-to-2020/

Glaeser, E., \& Gottlieb, J. (2009). The Wealth of Cities: Agglomeration Economies and Spatial Equilibrium in the United States. Journal of Economic Literature, 47(4), 983-1028.

Glowacki, J. B. (2012). The student loan debt crisis in perspective. Seattle, WA: Milliman. Green, R., \& Hendershott, P. H. (1996). Age, housing demand, and real house prices. Regional Science and Urban Economics, 26(5), 465-480.

Graneheim, U. H., \& Lundman, B. (2004). Qualitative content analysis in nursing research: concepts, procedures and measures to achieve trustworthiness. Nurse Education Today, 24(2), 105-112.

Gregory, J. (2016). How not to be an egalitarian: the politics of homeownership and property-owning democracy. International Journal of Housing Policy, 16(3), 337356.

Hess, A. (2017, June 23). Here's how much the average American in their 30s has in student debt. CNBC. Retrieved from http://www.cnbc.com/2017/06/23/heres..how-much-the-average-american-in-their-30s-has--in-student-debt.html 
Hamnett, C. (1999). Winners and Losers: Home Ownership in Modern Britain. London: UCL Press.

Harris, M. (2017). Kids These Days: Human Capital and the Making of Millennials. New York: Hachette Book Group.

Humphries, S. \& Rascoff, S. (2015). Zillow Talk: The New Rules of Real Estate. New York: Grand Central Publishing.

iQuantifi. Millennial Money Mindset Report. (2017). Retrieved from http://iquantifi.com/wp-content/uploads/2018/02/2017-iQuantifi-Millennial-.Money-Mindset--.Report.pdf

Johnson, C. L., Gutter, M., Xu, Y., Cho, S. H. \& DeVaney, S. (2016). Perceived Value of College as an Investment in Human and Social Capital: Views of Generations $X$ and Y. Fam Consum Sci Res J, 45, 193-207.

Johnson, R. (2017 October). The Missing Piece of the Millennial American Dream, Boom and Bust. Baltimore: Charles Street Publishing, LLC by Dent Research.

Joint Center of Housing Studies for Harvard University. (2017, December 14). America's Rental Housing 2017. Retrieved from http://www.jchs.harvard.edu/sites/jchs.harvard.edu/files/harvard_jchs america s_rental housing 2017.pdf

Joint Center of Housing Studies for Harvard University. (2017). Demographic Change and the Remodeling Outlook. Retrieved from http://www.jchs.harvard.edu/sites/jchs.harvard.edu/files/harvard jchs 2017 re modeling report chap1.pdf

Jones, C. (2015, April 11). For Millennials goal is financial freedom. USA Today, Retrieved by http://www.usatoday.com/story/money/personalfinance/2015/04/11/millennial s-want--a--different--kind--of--financial--planner/70832092/

Kalleberg, A. L. (2011). Good jobs, bad jobs: The rise of polarized and precarious employment systems in the United States, 1970s--2000s. New York: Russel Sage Foundation.

Kirk, M. (2017, April 14). Who will buy baby boomers homes? Retrieved from https://www.citylab.com/equity/2017/04/who-will--buy-baby-boomers-homes/522912/

Kusisto, L. (2017, June 7). Millions of Young People Shut Out of the Housing Market. The 
Wall Street Journal. Retrieved from https://www.wsj.com/articles/millions--of-young-people--shut-out-of-the--housing-market--1496836800

Lauster, N. T. (2010). Housing and the Proper Performance of American Motherhood, 1940-2005. Housing Studies, 25(4), 543-557.

Li, W. \& Yang, F. (2010). American Dream or American Obsession? The Economic Benefits and Costs of Homeownership. Federal Reserve Bank of Philadelphia Business Review, 20-30.

Lindblad, M. R., \& Quercia, R. G. (2014). Why Is Homeownership Associated with Nonfinancial Benefits? A Path Analysis of Competing Mechanisms. Housing Policy Debate, 25(2), 263--288.

Lobosco, K. (2017, August 22). Yes, student debt is delaying homeownership. CNN Money. Retrieved from http://money.cnn.com/2017/07/13/pf/college/student-. debt-home--ownership/index.html

Mackie, P. K. (2016). Young people and housing: identifying the key issues. International Journal of Housing Policy, 16(2), 137--143.

Malpass, P. (2006). Housing policy in an 'opportunity society'; home ownership and the amplification of inequality, in: J. Doling \& M. Elsinga (Eds) Home Ownership: Getting in, Getting from, Getting out; Part 2 (Amsterdam: IOS Press).

Mankiw, N. G. \& Weil, D. N. (1989). The baby boom, the baby bust, and the housing market. Regional Science and Urban Economics, 10(2), 235-258.

McKee, K. (2012). Young People, Homeownership and Future Welfare. Housing Studies, 27(6), 853-862.

Mckee, K., Moore, T., Soaita, A., \& Crawford, J. (2017). 'Generation Rent' and The Fallacy of Choice. International Journal of Urban and Regional Research, 41(2), 318-333.

Peek, J., \& Wilcox, J. A. (1991). The baby boom, "pent-up" demand, and future house prices. Journal of Housing Economics, 1(4), 347-367.

Pido, E. (2009). The Performance of Property: Suburban Homeownership as a Claim to Citizenship for Filipinos in Daly City. Institute for the Study of Social Change at UC Berkeley Working Paper Series, (1-45).

Prabhakar, R. (2009). The assets agenda and social policy. Social Policy \& Administration, 43(1), 54-69. 
Rakoff, R. (1977). Ideology in Everyday Life: The Meaning of the House. Politics and Society $7,85-104$.

Robaton, A. (2016, November 30). Preparing for the 30 trillion great wealth transfer. Retrieved from https://www.cnbc.com/2016/11/29/preparing-for-.the--30.trilliongreat-wealth-transfer.html

Rohe, W. M. \& Stegman, M.A. (1994). The Impacts of Home Ownership on the Self-Esteem, Perceived Control and Life Satisfaction of Low--Income People. Journal of the American Planning Association, 60(1), 173--184.

Rohe, W. M. \& Basolo, V. (1997). Long.--Term Effects of Homeownership on the Self..Perceptions and Social Interaction of Low-Income Persons. Environment and Behavior, 29(6), 793--819.

Rohe, W. M., Zandt, S., Van, \& McCarthy, G. (2001). The Social Benefits and Costs of Homeownership: A Critical Assessment of the Research. Low-Income Homeownership|Working Paper Series, (October), 1-35.

Rolnik, R. (2013). Late Neoliberalism: The Financialization of Homeownership and Housing Rights. International Journal of Urban and Regional Research, 37(3), 1058- 1066.

Ronald, R. (2008). The Ideology of Home Ownership; Homeowner Societies and the Role of Housing. Basingstoke: Palgrave Macmillan.

Salviati, Chris. (2018, January 25). Student debt and Millennials homeownership. Retrieved from (https://www.apartmentlist.com/rentonomics/student--debt-millennial-.homeowership/

Salviati, Chris \& Woo, Andrew. (2017, May 16). American dream of homeownership delayed for millennial generation. Retrieved from https://www.apartmentlist.com/rentonomics/millennials-and--homeownership.$\underline{2016 /}$

Sherraden, M. W. (1991). Assets and the Poor: A New American Welfare Policy. Armonk: Sharpe.

Smith, Susan J. (2005). Banking on housing? Speculating on the role and relevance of housing wealth in Britain. Project Report. Durham University: Durham. (1-39).

Storper, M., \& Scott, A. J. (2009). Rethinking human capital, creativity and urban growth. Journal of Economic Geography, 9(2), 147-167. 
The Southland Regional Association of Realtors. (2017). 80\% of Millennials Want a Home, but Few Save Enough. Los Angeles: Nancy Starczyk.

Thorne, Sally. (2008). Interpretive Description. Walnut Creek, CA: Left Coast Press.

Thomas, H. (2013). The Financial Crisis Hits Home: Foreclosures and Asset Exhaustion in Boston. Housing Policy Debate, 23(4), 738-764.

Vaismoradi, M., Turunen, H., \& Bondas, T. (2013). Content analysis and thematic analysis: Implications for conducting a qualitative descriptive study. Nursing \& Health Sciences, 15(3), 398-405.

Wilkinson, R. (2009). The Spirit Level. The Spirit Level: Why More Equal Societies Almost Always Do Better, 215-228.

van Gent, Wouter P. C. (2010). Housing Policy as a Lever for Change? The Politics of Welfare, Assets and Tenure. Housing Studies, 25(5), 735-753.

Zillow.com. (2018). Los Angeles County Home Prices \& Values. Retrieved from https://www.zillow.com/los--angeles--county-.ca/home--values 


\section{Appendix A. Interview Questions}

1. Are you from Los Angeles? If not, what brought you here?

2. Are you currently renting or owning?

3. Can you tell me about your experience here finding your current place?

4. Which obstacles to obtaining your apartment/home were particularly challenging?

5. [If renting] Are you content with renting right now? Would you like to owna home in the future?

6. [If yes] What would need to happen for you before you could own a home? Are there particular obstacles between you and homeownership that you feel are especially significant?

7. [If no to \#5] Are you content to continue renting? What do you think are the financial benefits to renting?

8. [If owning] Are you content with your investment thus far? What are your goals for this investment, what do you hope to obtain from it?

9. Do you spend much time planning for your financial future? Do you feel that currently you have the knowledge and skills to make smart decisions with your finances?

10. When you are thinking about future financial security, what types of investments do you plan to make? What steps do you plan to take to ensure financial security?

11. If financial security is not a huge concern for you right now, what are more pressing financial concerns that you have?

12. Do you view housing as a problem or a solution to those financial concerns?

13. Did your parent's own a home? Do they still own the same one you grew up in?

14. [If yes\} Do you think that your homeownership experience will be significantly different from theirs? Why or why not?

15. What do you think and how do you feel when you hear the term 'American Dream'?

16. Is that Dream something that you hope to achieve? Why or why not? If yes, do you think it is attainable?

17. Do you feel that your financial goals are significantly different from your parents'? If yes, why do you think that is?

18. What does well-off mean to you?

19. Do you think that homeownership has societal benefits? 
20. If you could change anything about the current U.S. housing market rightnow, what would you change?

21. Does the structure of the housing market make you feel empowered or disempowered? What factors make you feel that way? 


\section{Appendix B. Outline of Themes}

- American dream

- Traditional

- Perpetuates injustice

- Sold as a lie

- Still something to strive for

- New American Dream

- Good quality of life now

- Freedom from oppression/judgment

- Individualism over cookie cutter

- International perspective

- Homeownership represents citizenship

- USA is still land of opportunity

- Specialization

- Access to technology

- Poor K--12 education

- American dream is freedom to choose career

- Los Angeles

- The city is worth its high price

- It is impossible to live the American dream in LA

- Homeownership is impossible in LA except for the very wealthy

- High cost of housing a major constraint/driver in housing choices

- Affordability

- No one is immune

- Incomes are not enough

- Cost of living is out of control

- Student Loans

○ Difficulty saving

- Cost of tuition too high

- Debt averse

- Not willing to take on a mortgage

- Loans affect housing pathways

- Moving back home

- Multiple roommates

- Student loans are a new problem for young people

- Labor market changes

- Waiting for baby boomers to retire

○ Tech

- Jobs are changing

- Everything is faster

- Working remotely

o Health insurance/retirement tied to employment 
- Jobs don't provide training

$\circ$ Stagnating wages

- Attitudes towards homeownership---positive

o Freedom

- Freedom to make changes

- Stability

- Having a home base

- Building equity

- Not having to pay rent

- Range in attitudes and preferences

- Information makes it less intimidating

- Attitudes towards homeownership--negative

O Owning things causes stress

- Don't want to lose a house in the next downturn/recession

- Too expensive

- Homeownership doesn't fit lifestyle

- Homeownership easier for baby boomers

- Home preferences

- Small homes

- Affordable homes

- Urban location

- Delayed life stages-reasons

- Focus on personal development

- Marriage and kids is a big responsibility

- It takes longer to become financially stable

- It takes longer to establish a career

- Settling down not a priority

- When Millennials get married they will be more interested in homeownership

- Parents

- Support (or lack thereof) impacts current financial situation, especially paying for college

- Homeownership more attainable with parent support

- Millennials attitudes towards baby boomers

- Baby boomers had it easier

- Resentment

- Blame

- Lack of understanding/empathy for Millennials

○ Boomers think Millennials are entitled/incompetent 
- Unlike boomers, Millennials question everything

- Social movements

- Mobility for career

- Career is the top priority

- Jobs now are short--term/can lead to moving

- Renting makes more sense for transitory lifestyle

- Prioritizing traveling/experiences

- Millennials very mobile generation

- Retirement

- Many pathways to retirement

- Cannot rely on government for any help

- Uncertainty

- A problem for the future

- Uncertainty/short-term thinking

o Too many options

- Difficulty making decisions

- Difficulty making commitments

- Anxiety over the future

- Things are unpredictable

o Focused on enjoying the present

- Individual values

- Values significantly determine housing pathway

- Experiences over things

- Status symbols and definitions of success evolving

- This affects self-.efficacy and self-.esteem

- Collective values

- Individualism

- Cultural shift in values could solve a lot of problems

- Current societal and economic values lead to injustice

- Millennial values in Los Angeles more liberal

- Return to local scale

- Racism

- The American dream has a different meaning for black families

- It means that hopefully things will get easier for the next generation

- Racism affects Millennials of color in education, the labor market, and housing

- Black families historically shut out from homeownership and unable to build equity-where are we now?

- Government role

- Frustration from all sides

- Failure to provide affordable housing

- Lack of trickle down 
- Alternative pathways/housing models

- Millennials want more options

- Current options aren't affordability

- Housing in the future will look different

- Self-efficacy

- Range within sample size

- Low self-efficacy reflects real barriers/obstacles to financial goals 